The Design, Fabrication, and Testing of WETF High-Quality, Long-Term-Storage, Secondary Containment Vessels

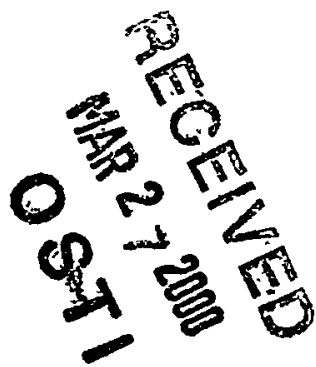
for the United States Department of Energy under contract W-7405-ENG-36. 
An Affirmative Action/Equal Opportunity Employer

This report was prepared as an account of work sponsored by an agency of the United States Government. Neither The Regents of the University of California, the United States

Government nor any agency thereof, nor any of their emiployees, makes any warranty, express or implied, or assumes any legal liability or responsibility for the accuracy, completeness, or usefulness of any information, apparatus, product, or process disclosed, or represents that its use zould not infringe privately owned rights. Reference herein to any specific commercial product, process, or service by trade name, trademark, manufacturer, or otherwise, does not necessarily constitute or inply its endorsement, recommendation, or favoring by The Regents of the University of California, the United States Government, or any agency thereof. The views and opinions of authors expressed herein do not necessarily state or reflect those of The Regents of the University of California, the United States Government, or any agency thereof. Los Alamos National Laboratory strongly supports academic freedom and a researcher's right to publish; as an institution, however, the Laboratory does not endorse the viewpoint of a publication or guarantee its technical correctness. 


\section{DISCLAIMER}

Portions of this document may be illegible in electronic image products. Images are produced from the best available original document. 
The Design, Fabrication, and Testing of WETF High-Quality, Long-Term-Storage, Secondary Containment Vessels

Kane J. Fisher

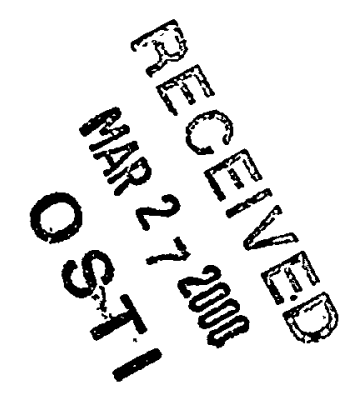




\title{
THE DESIGN, FABRICATION, AND TESTING OF WETF HIGH-QUALITY, LONG-TERM-STORAGE, SECONDARY CONTAINMENT VESSELS
}

by

Kane J. Fisher

\begin{abstract}
Los Alamos National Laboratory's Weapons Engineering Tritium Facility (WETF) requires secondary containment vessels to store primary tritium containment vessels. The primary containment vessel provides the first boundary for tritium containment. The primary containment vessel is stored within a secondary containment vessel that provides the secondary boundary for tritium containment. WETF requires high-quality, long-term-storage, secondary tritium containment vessels that fit within a Mound-designed calorimeter. In order to qualify the WETF high-quality, long-term-storage, secondary containment vessels for use at WETF, steps have been taken to ensure the appropriate design, adequate testing, quality in fabrication, and acceptable documentation.
\end{abstract}

\section{INTRODUCTION}

The Weapons Engineering Tritium Facility (WETF) uses secondary containment vessels to store primary tritium containment vessels. The primary containment vessel is the first boundary used for tritium containment. The primary container is stored in a secondary containment vessel that provides the second tritium boundary. In order to assay the quantity of tritium contained within the secondary containment vessel, it must fit within the WETF Mound-designed calorimeter. Of the existing secondary containment vessels at WETF, only one design can be placed within the calorimeter to assay the quantity of tritium contained within the vessel.

The Tritium Operations Engineering team at WETF was tasked in February 1999 with providing secondary containment vessels for WETF that fit within the calorimeter. The use of secondary containment at WETF originates from the safe handling and storage of primary tritium vessels within high-quality secondary containers. Secondary containment is crucial to limiting the release of tritium or tritiated water into the room atmosphere at WETF. 


\section{REQUIREMENTS}

These vessels were to be designed and fabricated with the engineering rigor and design requirements of a high-quality, secondary tritium containment vessel as defined by the Department of Energy (DOE) Document, DOE HDBK-1129-99, Tritium Handling and Safe Storage. This design requirement includes the requirement that the vessel be designed and fabricated in accordance with the American Society of Mechanical Engineers (ASME) Boiler and Pressure Vessel Code.

A design requirement of the WETF high-quality, long-term-storage, secondary containment vessel was to establish a pedigree and set a design, fabrication, and testing standard that could be used for all future secondary containment vessels at WETF. The Tritium Operations Engineering team at WETF used the Mound design in the fabrication of the new WETF high-quality, long-term-storage, secondary containment vessels. In the manufacture of these secondaries, the Mound drawing \# AYD901039, Revision 4, was modified and redrawn to produce a new drawing for the containers. This drawing of the newly manufactured WETF high-quality, long-term-storage, secondary containment vessels, WETF drawing number 141Y-634984, is shown in Appendix A.

The required maximum allowable working pressure (MAWP) for these vessels was $200 \mathrm{psig}$. The required outside diameter is 6.844 inches (see Appendix A). This diameter is for a close tolerance fit between the vessel and the WETF calorimeter. This close tolerance allows for faster achievement of thermal equilibrium within the calorimeter and thus reduces measurement times.

The Mound-designed containers originally carried a certain pedigree that included calculations, material specifications, fabrication specifications, and testing. With the closure of Mound Laboratory, the loss of knowledgeable personnel, and wholesale elimination of files, this Mound pedigree was lost. Mound sent LANL a secondary container that was designed to fit within the calorimeters. This vessel was fabricated at Mound, serial \# 012 , according to Mound drawing \# AYD901039, Revision 4. WETF had a need for more of the secondaries in 1993 and had six more manufactured according to the Mound drawing \# AYD901039, Revision 4.

A requirement of the vessel is to limit the weight because WETF personnel must lift the vessel up into the calorimeter. The vessel was constructed using 2024-T351 aluminum that gives the vessel an empty weight of 19.5 pounds.

The WETF high-quality, secondary containment vessel must have no detectable leak below $1.0510^{-8}$ standard- $\mathrm{cm}^{3} / \mathrm{s}$ helium. This leak test is performed with the vessel pressurized with helium at the MAWP. After the manufacture and assembly of the vessel, it must also pass a 5-minute-proof pressure test with no permanent deformation, visible cracks, or leaks. This proof test is at $150 \%$ of the MAWP. 
The WETF high-quality, long-term-storage, secondary containment vessel must survive a 10-foot drop onto concrete, because it will be lifted by WETF personnel into the calorimeter and there exists a possibility of its being dropped. The drop survivability of the WETF high-quality, secondary containment vessel was determined by dropping containers with an orientation so that they hit the Nupro $4 \mathrm{H}$ valve or the Ashcroft pressure gauge. These parts are considered the most vulnerable to damage from a drop. The drop tests were performed with the MAWP of $200 \mathrm{psi}$ helium. After the drop tests the vessels must pass a helium leak check (see Appendix B).

A requirement for the WETF high-quality, long-term-storage, secondary containment vessel is to be manufactured from parts that have a temperature rating higher than $200^{\circ} \mathrm{F}$. The WETF high-quality, long-term-storage, secondary containment vessel can use either a Nitrile O-ring or a Helicoflex all metal seal. The Nitrile O-ring has a usable temperature of up to $275^{\circ} \mathrm{F}$. The Helicoflex close-wound, helical spring seal has a maximum usable temperature of $482^{\circ} \mathrm{F}$. The Nupro SS-4H-W96 valve has an all-metal stem tip that enables the valve to have a maximum usable temperature of $600^{\circ} \mathrm{F}$.

Also in the design requirements of the WETF high-quality, long-term-storage, secondary containment vessels, the DOE Handbook, Design Considerations, DOE-HDBK-1132-99 was used as a guide for the selection of the materials and construction of the high-quality, WETF secondary containers.

\section{FABRICATION}

The machining and manufacture of the 110 secondary containers were submitted through a competitive bid process to three fabrications shops that were deemed by ESA-WMM to be competent enough to complete the fabrication. Bogue Machine Company, Inc., in Albuquerque won the bid and started to order materials in March of 1999. Manufacture started soon thereafter and was completed in June 1999. Throughout the manufacture of the WETF high-quality, long-term-storage, secondary containment vessels, visits and preliminary inspections were made by Kane J. Fisher at Bogue Machine Company, Inc., in Albuquerque.

\section{TESTING, CALCULATIONS, AND MATERIAL SPECIFICATIONS}

The qualification and subsequent pedigree of these secondary containers emanated from a series of physical tests, calculations, and material specifications. Each container has an identical machined serial number and the MAWP on both the top flange and bottom piece. An inspection was performed at Bogue on 20 out of 110 pieces for compliance to 24 different specifications. This inspection was done before delivery of the vessels to LANL. These 20 vessels were considered a representative sample of the total vessels made. Each of the 20 vessels inspected was within the tolerances for each of the given 24 specifications. A picture of a completed WETF high quality secondary is shown in Figure 1. 


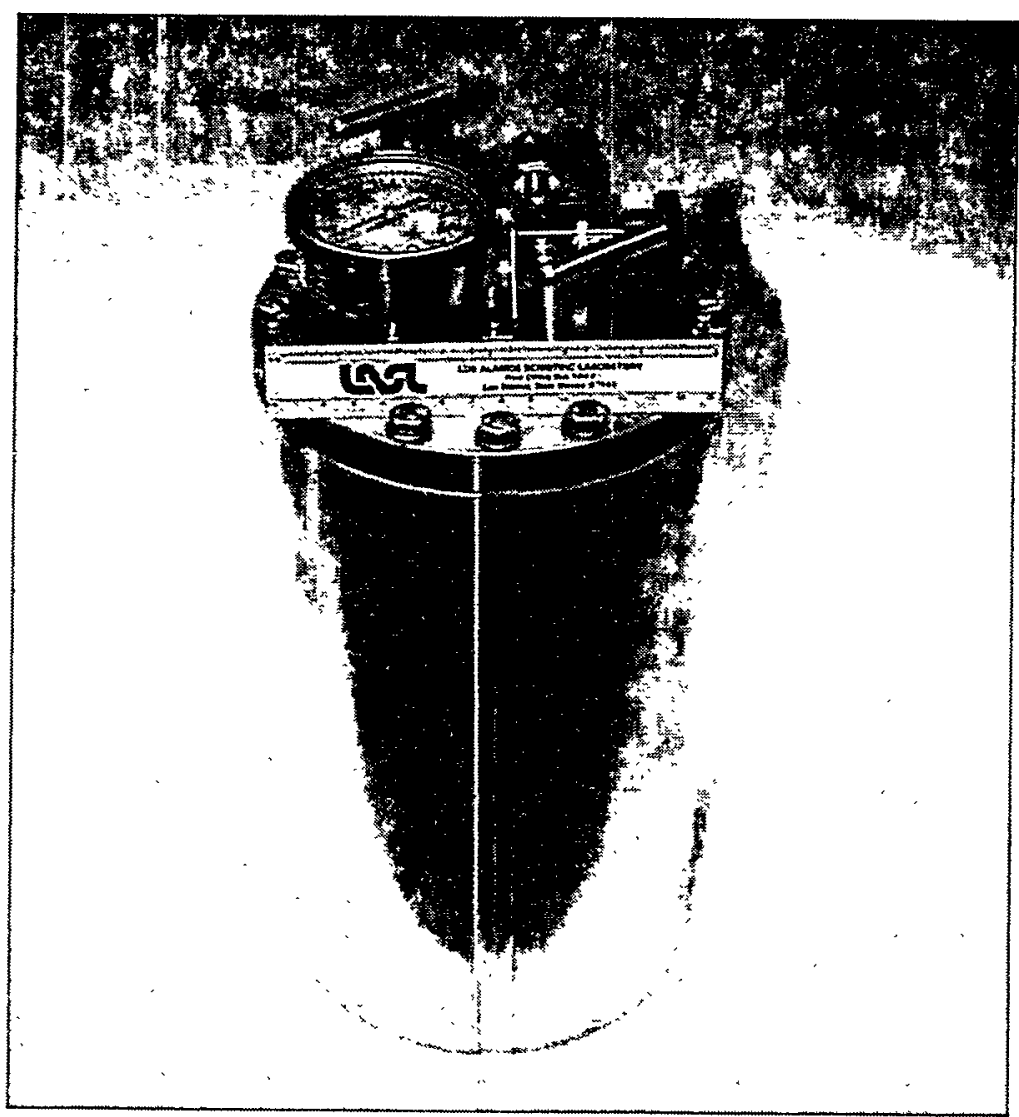

Figure 1. WETF high-quality, secondary container.

The physical tests performed on the WETF secondary containers were helium leak tests at the MAWP, proof tests to $150 \%$ of the MAWP, pressure rise to failure (burst test), and destructive drop tests at the MAWP.

A certified Level-II Helium leak tester performed an inside-out leak test on the WETF secondary containers in a bell jar. This leak test must be performed and documented on each WETF high-quality, long-term-storage, secondary containment vessel before it can be used. The WETF high-quality, long-term-storage, secondary containment vessels were placed within a bell jar and pressurized to the MAWP of $200 \mathrm{psig}$. The bell jar was then evacuated and the true helium leak rate of all sealing surfaces was determined. A leak rate greater than $1.0510^{-8} \mathrm{standard}-\mathrm{cm}^{3} / \mathrm{s}$ helium is not acceptable. 
A proof test with helium gas is performed to $150 \%$ of the 200 psig MAWP. In this proof test, 300 psig gas pressure is loaded into the WETF secondary container and left for 5 minutes. The proof test is performed in a bell jar, and the helium leak detector can detect any leaks. This proof test must be performed and documented on all of the WETF secondary containers before they can be used. Any visible cracks, leaks, or deformation within this 5-minute period at the proof pressure constitutes a failure of the proof test, and the container is not acceptable.

Three WETF secondary containers (serial numbers $26,51,76$ ) were burst-test (pressure rise to failure) with helium gas pressure. The burst pressures were 3,369.0 psig, 3,480.0 psig, and 3,480.0 psig, respectively. This burst pressure is 17 times the MAWP of $200 \mathrm{psig}$ and is greater than the ASME required safety factor of four times the MAWP.

The containers were placed inside a "boom ball" and plumbed to a high pressure compressor. The gas pressure was increased until there was a failure in the containment of the gas. Each one of the containers tested failed by blow-by on the O-ring seal, which is a desirable failure, shown in Figure 2. There were no catastrophic or projectile producing failures.

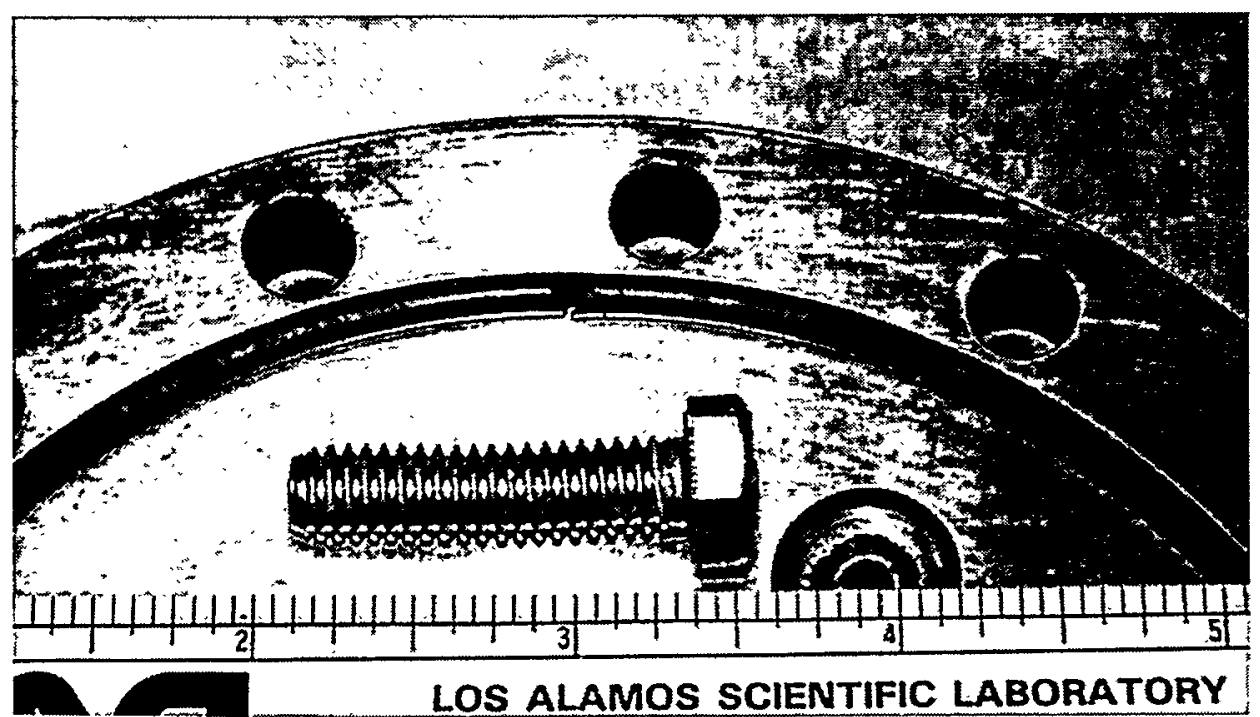

Figure 2. Blow-by on the O-ring and stressed bolt. 
A picture of a profile view of the top lid after burst testing of the container shows the deformation of the $5 / 8$ " thick 304L stainless-steel lid, Figure 3.

The bourdon tubes within the 300 psig Ashcroft gauges, shown in Figure 4, were deformed but did not rupture. These burst tests served two main purposes. One purpose was to determine the ultimate pressure that the WETF secondary containers could withstand before a breech of containment occurred. Another purpose was to determine where the container would fail and whether the failure would be violent.

The Tritium Operations Engineering Team performed three drop tests to determine the survivability of the WETF secondary containers if dropped. The test was to determine whether an Ashcroft pressure gauge that had been overpressurized would survive a direct hit from 10 feet. The WETF secondary container, serial number 51 , was first burst-tested (pressure rise to failure), then dropped onto the Ashcroft pressure gauge. The pressure at burst of serial number 51 was 3480 psia. The WETF Tritium Operations Engineering Team manufactured a neoprene gasket that could be used to reseal the container and checked the integrity of the container by helium leak checking. The container was filled with helium to S-Site atmospheric pressure. The container was then dropped from 10 feet onto the Ashcroft pressure gauge. The WETF secondary container, serial number 51, maintained its integrity, which was determined by a post helium leak test.

Two other drop tests were performed with ESA-MT at K-Site Reduced Hazard Area. ESA-MT prepared the Experimental Test Instruction (ETI), which is included in Appendix B. This ETI is a requirement for performing experiments at the drop tower at $\mathrm{K}$-Site. The two drop tests were performed with 200 psig helium gas pressure within the WETF secondary containers. Each of the containers was helium leak checked before being taken to K-Site. A 13-pound piece of aluminum stock was placed inside both WETF high-quality, long-term-storage, secondary containment vessels to provide a mass mockup for the primary containment vessels that will be stored in them. The drop tests were onto concrete from a height of 10.0 feet. One container, serial number 20 , was dropped at a $45^{\circ}$ angle onto the Ashcroft pressure gauge. The Ashcroft gauge was damaged as shown in Figure 5.

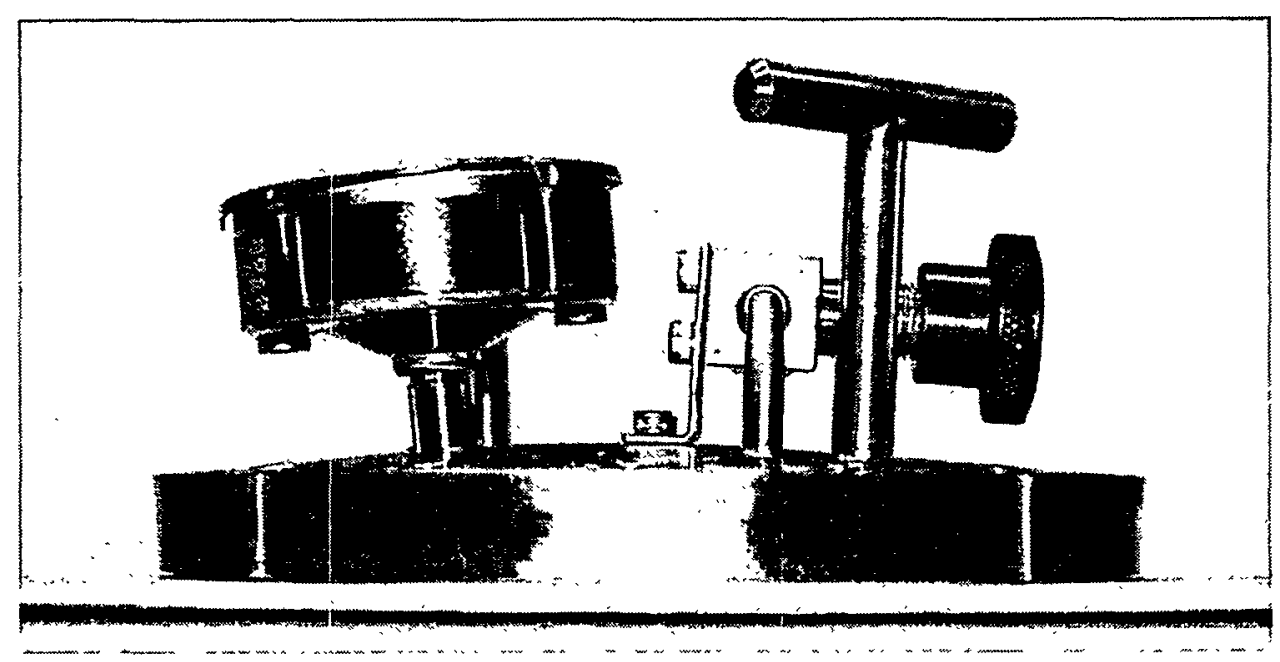

Figure 3. Deformation of 5/8" stainless-steel lid. 


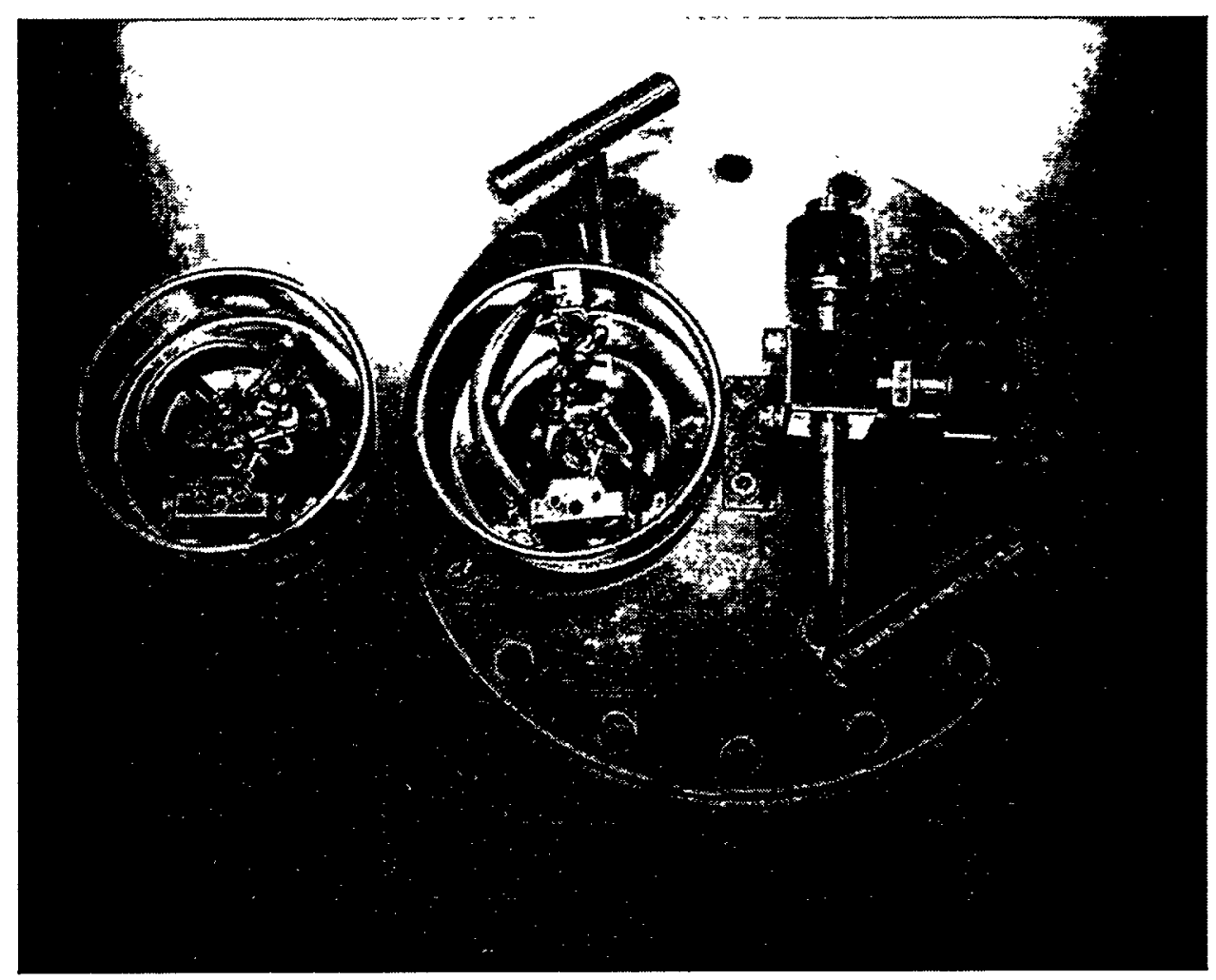

Figure 4. Comparison of deformed bourdon tubes.

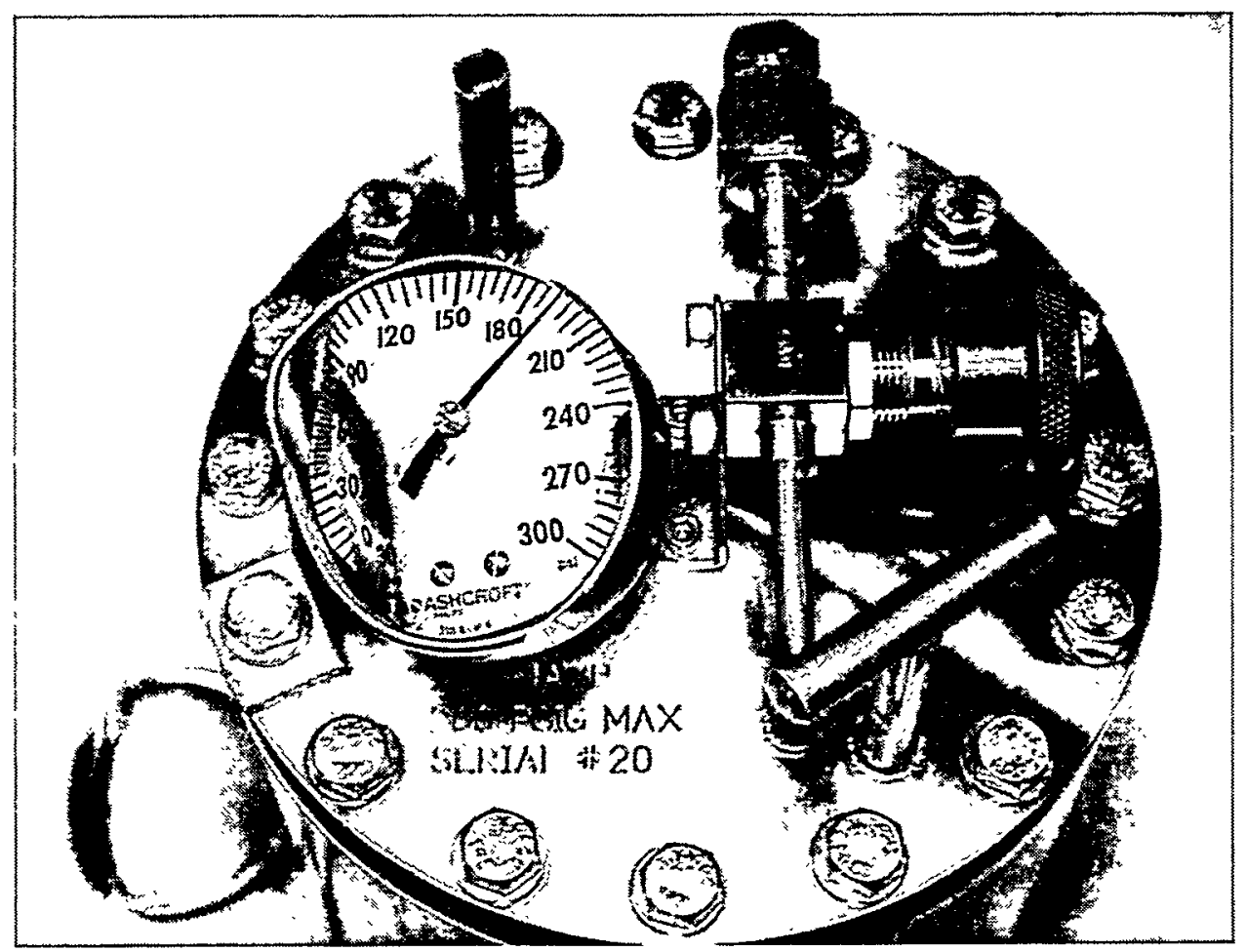

Figure 5. Damage to Ashcroft gauge from 10-ft drop test. 
The other container, serial number 50 , was dropped at a $45^{\circ}$ angle onto the Nupro $4 \mathrm{H}$ valve. The $4 \mathrm{H}$ valve handle was damaged and the 1/4-in. stainless-steel tube was bent as shown in Figure 6. The drop tests were performed remotely from Building K-3 following the procedure written in the ETI. Each container was helium leak checked afterwards by a certified Level-II leak checker, and each had a leak rate after the drop test of less than $1.0 \times 10^{-6}$ standard $\mathrm{cm}^{3} / \mathrm{s}$ helium.

Calculations, as well as testing, are integral parts of the acceptance and use of the WETF high-quality, secondary containers. The DOE Handbook, "Design Considerations," DOE-HDBK-1132-99; and the DOE Handbook, "Tritium Handling and Safe Storage," DOE-HDBK-1129-99, endorse the use of the ASME Boiler and Pressure Vessel code as a guideline for producing a tritium containment vessel. A certified ASME Boiler and Pressure Vessel Code Inspector, James Radigan, Professional Engineer, PE license number 31350 Colorado, performed pressure rating calculations for the WETF secondary containers. James Radigan's ASME calculations approved the MAWP of 200 psig for the WETF high-quality, secondary containers. These Professional Engineer stamped calculations are contained in the Appendix C. It was the intention of the Tritium Operations Engineering team to have these calculations performed independently of the manufacturer and of Los Alamos National Laboratory.

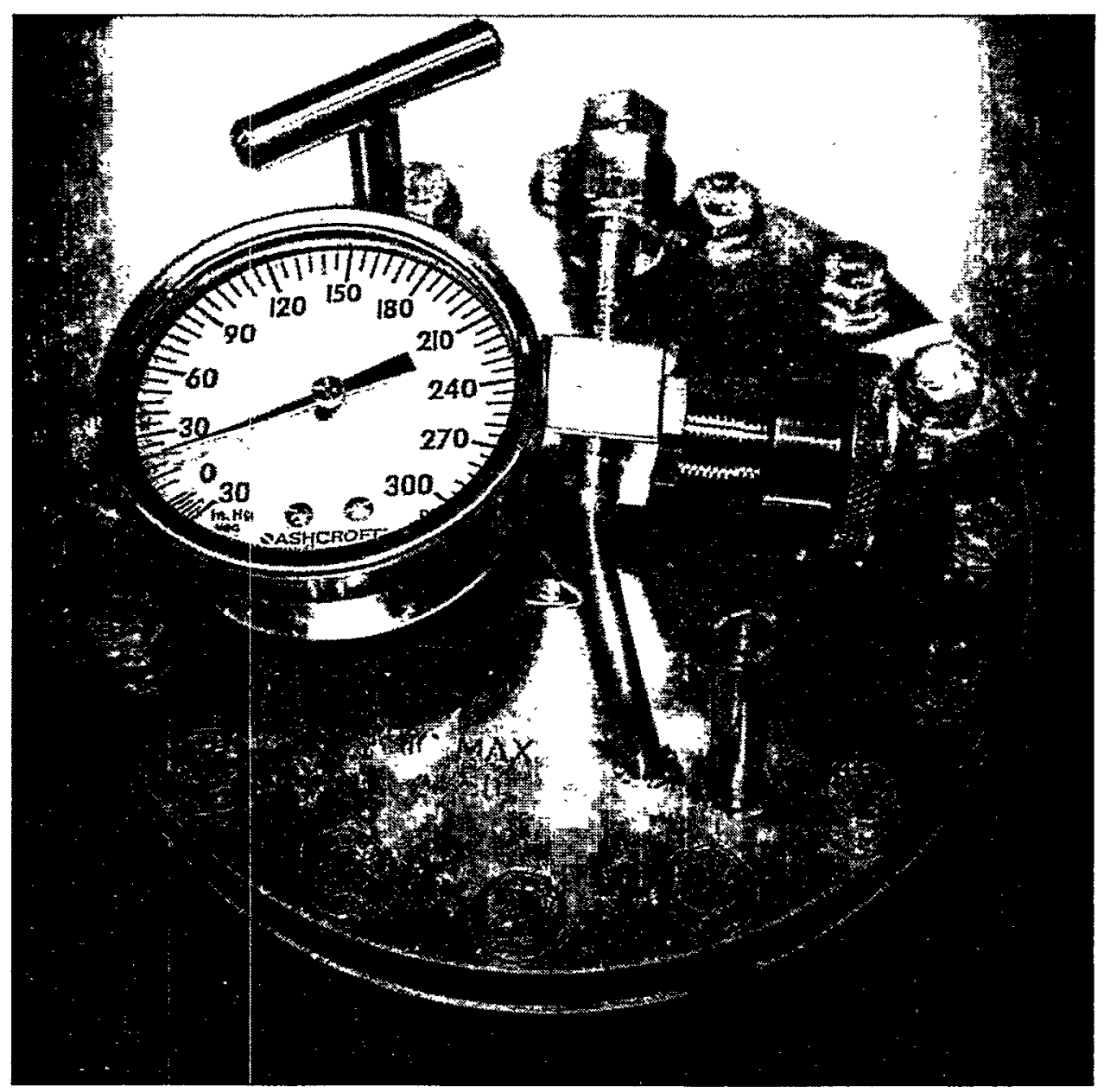

Figure 6. Damage to the Nupro $4 \mathrm{H}$ valve from 10 -ft drop test. 
The material specifications for the WETF high-quality, secondary containers are materials that are suggested for tritium service in the DOE Handbook, "Design Considerations," DOE-HDBK-1132-99; and the DOE Handbook, "Tritium Handling and Safe Storage," DOE-HDBK-1129-99. The lower portion of the container is made of 2024-T351 aluminum. Aluminum is used to minimize the weight of the container because WETF personnel must manually lift these containers. This particular aluminum was used because of the very high strength and mechanical properties. The Aluminum Associations temper designation, -T351 is used by industry, Machinery's Handbook, $25^{\text {th }}$ Ed. The temper - T351 explains that the aluminum is solution heat-treated, cold-worked, and stress-relieved by stretching $1 \%$ to $3 \%$ of the permanent set, from Machinery's Handbook, $25^{\text {th }}$ Ed. Bogue Machine Company purchased the 2024-T351 aluminum from the Kaiser Aluminum \& Chemical Corporation. One of the Kaiser Aluminum \& Chemical Corporation materials certification reports for the 2024-T351 aluminum is included in Appendix D. This certified test report lists the actual physical properties of the aluminum as well as the weight percent of the chemical composition.

The top lid of the container is made of $304 \mathrm{~L}$ (low carbon) stainless steel. This steel is desirable for tritium service because it provides good strength, weldability, and resistance to hydrogen embrittlement. A certificate of tests for the bar stock $304 \mathrm{~L}$ from Ugine-Savoie, France is included in Appendix E.

The selection and use of the Nupro $4 \mathrm{H}$ valve was done because of reliability in tritium service. The Nupro $4 \mathrm{H}$ valve was received from the factory with a 3.0-in. tube extension, female end cap, and a Vespel stem tip. Receiving this Nupro $4 \mathrm{H}$ valve this way from the factory saved Bogue Machining Inc. two difficult welds on the valve. The Vespel stem tip has shown good reliability in tritium service as long as the valve is not repeatedly overtightened. The WETF operators are trained about the consequences of overtightening Nupro $4 \mathrm{H}$ valves as part of their facility operator certification. The valves are made of $316 \mathrm{~L}$ (low carbon) stainless steel, which is desirable for tritium service because it provides good strength, weldability, and resistance to hydrogen embrittlement, much like 304L stainless stẹel.

The Ashcroft 300 psig pressure gauge was also selected because of its all stainless-steel construction on the wetted surfaces. This Ashcroft gauge has 1/4-in. NPT threads that provide bonding strength to the stainless-steel lid. The Ashcroft gauge and the Nupro $4 \mathrm{H}$ valve were both welded to the lid by a certified $6 \mathrm{G}$ welder by Bogue Machining, Inc. The seal on the top lid of the WETF high-quality, secondary container is made with an O-ring, or a Helicoflex seal. The O-ring selected is a Parker Seals O-ring, part number 2-252 (Nitrile, BUNA-N). This O-ring is compounded for service over a temperature range of $-65^{\circ} \mathrm{F}$ to $275^{\circ} \mathrm{F}$, from Parker O-ring Handbook. Although Nitrile is compatible for tritium service an all-metal seal can also be used. The Helicoflex seal is an all-metal seal that can be used in the WETF high-quality, secondary containers. Because of the all-metal characteristics of the Helicoflex seals, they are only used once. The Parker O-rings will be used when the WETF high-quality, secondary containers can be reused. 


\section{REFERENCES}

1. Tritium Handling and Safe Storage, Department of Energy document DOE HDBK-1 129-99 (1999).

2. DOE Handbook Design Considerations, Department of Energy document DOE-HDBK-1132-99 (1999)

3. Machinery's Handbook, $25^{\text {th }}$ Edition, (Industrial Press Inc., New York, NY, 1996).

4. Parker O-Ring Handbook, (Parker Hannifin Corporation, Cleveland, Ohio, 1992). 


\section{APPENDICES}

A. WETF drawing number 141Y-634984

B. ESA-MT prepared Experimental Test Instruction (ETI)

C. Photocopy of ASME calculations by James Radigan, PE

D. Kaiser Aluminum \& Chemical Corporation material certification report

E. Ugine-Savoie, France, certificate of tests for the bar stock 304L 


\section{Appendix A}

\section{WETF drawing number 141Y-634984}


Appendix A 


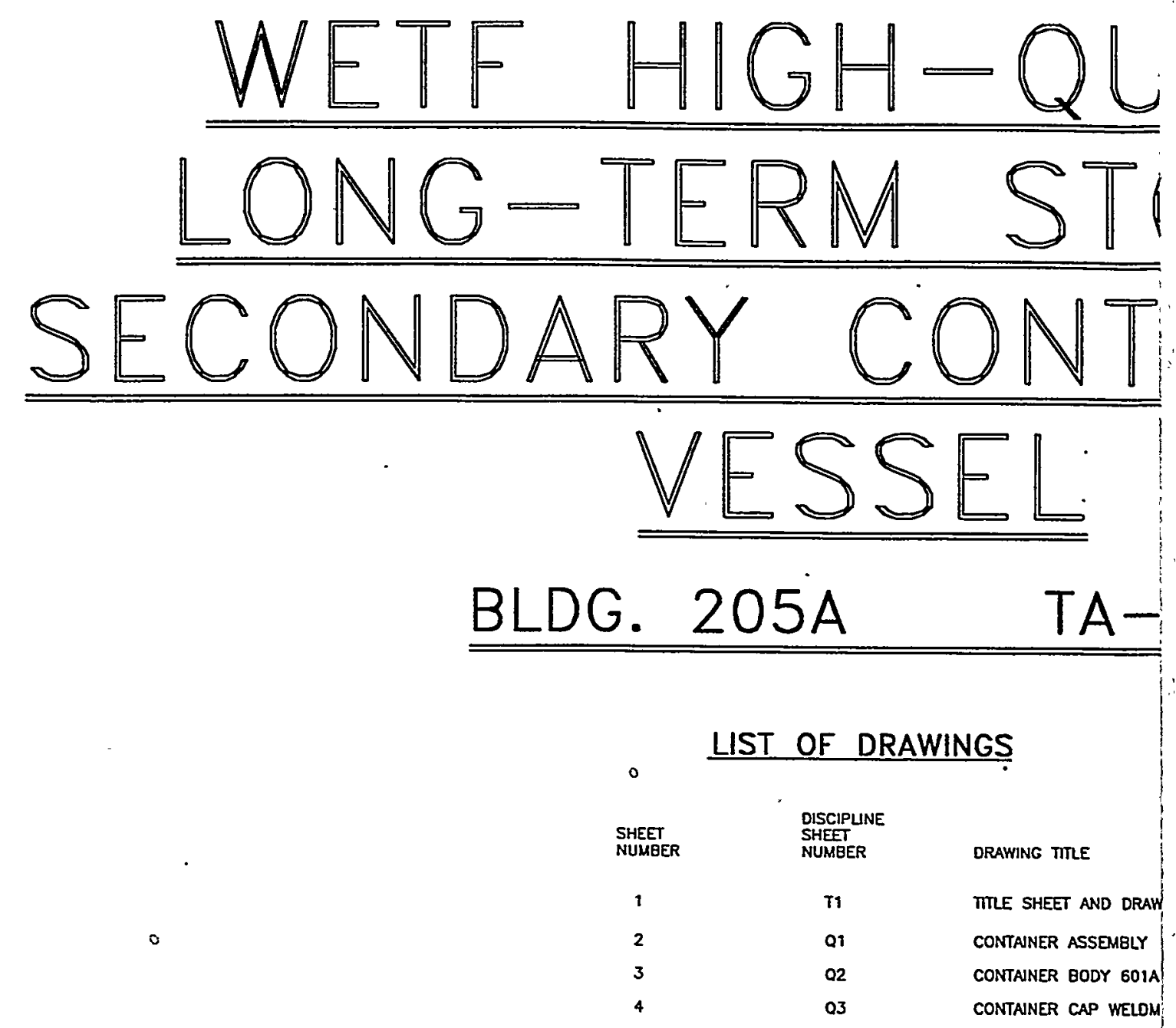



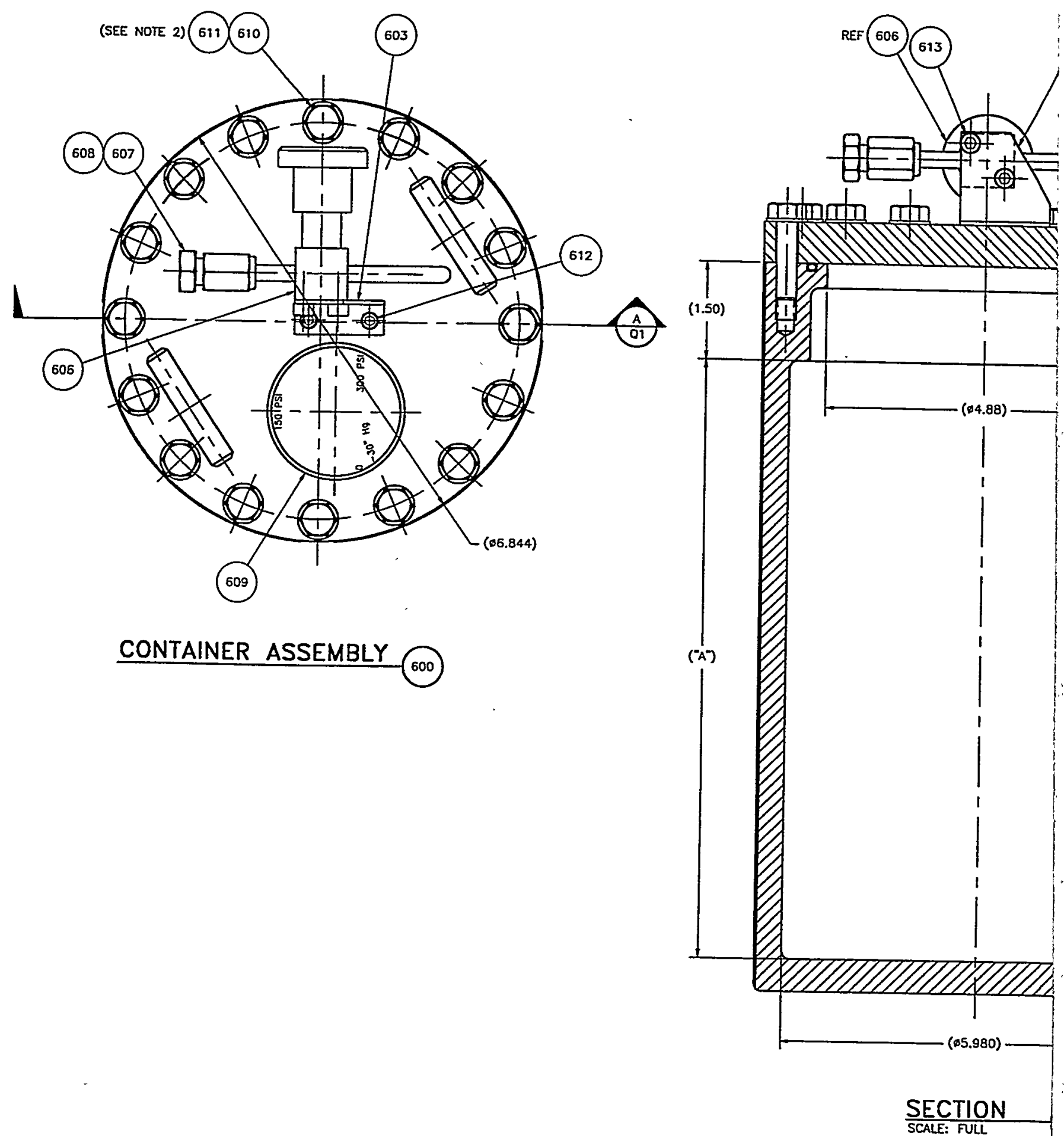
RE3 REF

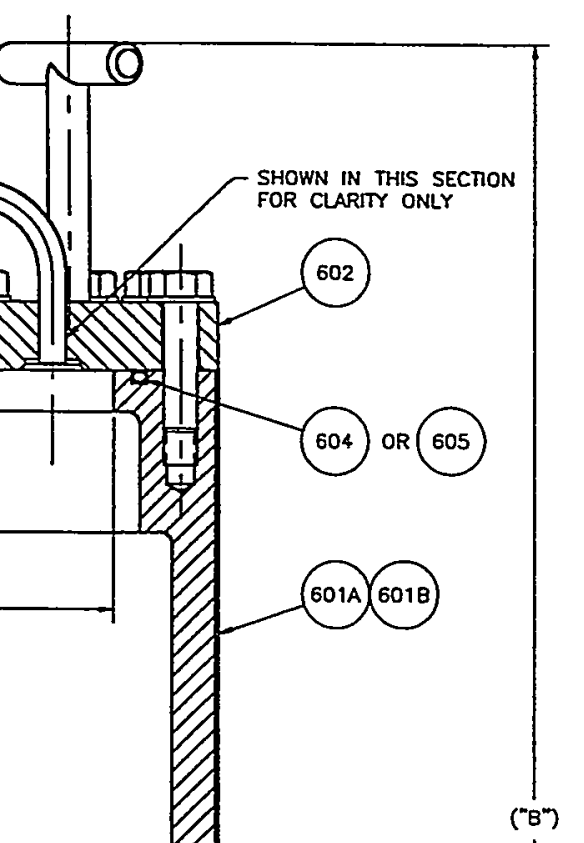

(A)
PARTS LIST

\begin{tabular}{|c|c|c|c|c|c|}
\hline \multicolumn{2}{|c|}{ quNmr } & \begin{tabular}{|l|l|} 
PNRT \\
NULBER \\
\end{tabular} & $\begin{array}{l}\text { REFERERCEE } \\
\text { DRUTNNG }\end{array}$ & $\begin{array}{l}\text { SHAET } \\
\text { NUMEER }\end{array}$ & \multirow{2}{*}{ 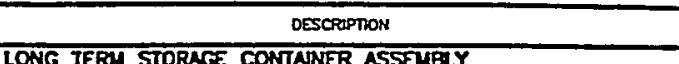 } \\
\hline & 2 & 600 & & & \\
\hline & & & & & \\
\hline & 600 & & & & \\
\hline & & & & & \\
\hline & $\overline{1}$ & 601A & & 2 & CONTAINER BODY \\
\hline & 1 & $601 \mathrm{~B}$ & & 2 & CONTANER BODY \\
\hline & 1 & 602 & & $\overline{3}$ & CONTAINER CAP WELDMENT \\
\hline & 1 & 603 & & 3 & VALVE SUPPORT BRACKEI \\
\hline & 1 & 604 & & & $\begin{array}{l}\text { SPRING SEAL: } 0.132 \text { SECTION, } 55.492(+.000,-.010) \\
\text { NIMONIC SPRING, ALUMINUM JACKET, INCONEL } 600 \text { LINING. } \\
\text { HEUCOFLEX CO. PART }\end{array}$ \\
\hline & 1 & 605 & & & O-RING: PARKER I2-252, NITRILE \\
\hline & 1 & 606 & & & $\begin{array}{l}\text { BELLOWS SEALED VALVE: NUPRO COMPANY (SWAGELOK) } \\
\text { MODEL } \$ 5 S-4 H-W 96\end{array}$ \\
\hline & 1 & 607 & & & VCR PLUG: CANON CO. MOOEL ISS-4-VCR-P \\
\hline & 1 & 608 & & & VCR GASKET: CAION CO. MODEL HSS-4-VCR-2 \\
\hline & 1 & 609 & & & $\begin{array}{l}\text { PRESSURE GAUGE: } 30^{*} \mathrm{Hg} \text { VACUUM TO } 300 \text { PSI, } 2 \text { DIAL SIZE, } \\
\text { ASHCROFT MODEE } \$ 25-1009-S W-028\end{array}$ \\
\hline & 16 & 610 & & & CAP SCREW: $5 / 16-18$ UNC $\times 1 / 4$ LG. HEX HD. SST \\
\hline & 16 & 611 & & & FLAT WASHER: CARR LANE MFG. CO. $\| \mathrm{Cl}-256$ \\
\hline & 2 & 612 & & & CAP SCREW: $8-32$ UNC $\times 3 / 8$ LG, SOCKET HD, SST \\
\hline & 2 & 613 & & & CAP SCREW: $10-32$ UNF $\times 1 / 4 \quad$ LG, SOCKET HD. SST \\
\hline
\end{tabular}

\section{NOTES:}

1. TORQUE TO 8 FT-LBS.

2. PARTS TO BE THOROUGHLY CLEANEO TO REMOVE ALl OIL, GREASE, OIRT. AND CHIPS.

3. WELO IN ACCORDANCE WITH ANSI/AWS D1.1 AND 010.4-1996

4. LEAK RATE OF ASSEMBLEO UNIT TO BE LESS THAN 1 E-8 ATM-CC/SEC. He AT MAWP

5. PRESSURE TEST TO 300 PSIG HELUM FOR A PERIOD OF $S$ MINUTES WTTH NO PERMANENT DEFORMATION, VISIBLE CRACKS, OR LEAKS.

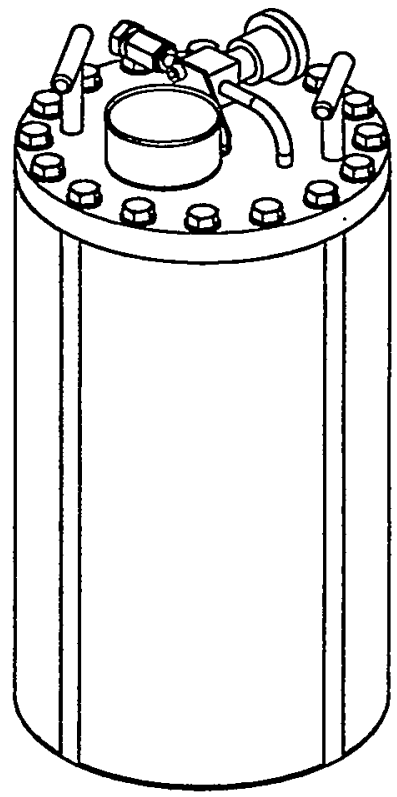

WETF GROUP NO.

WETF-DR-GEN-157

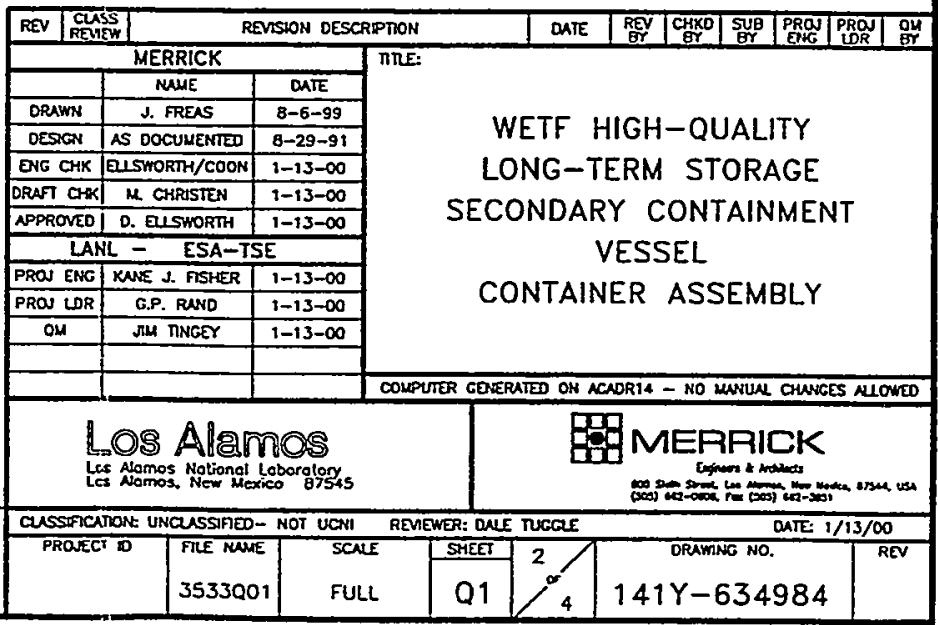




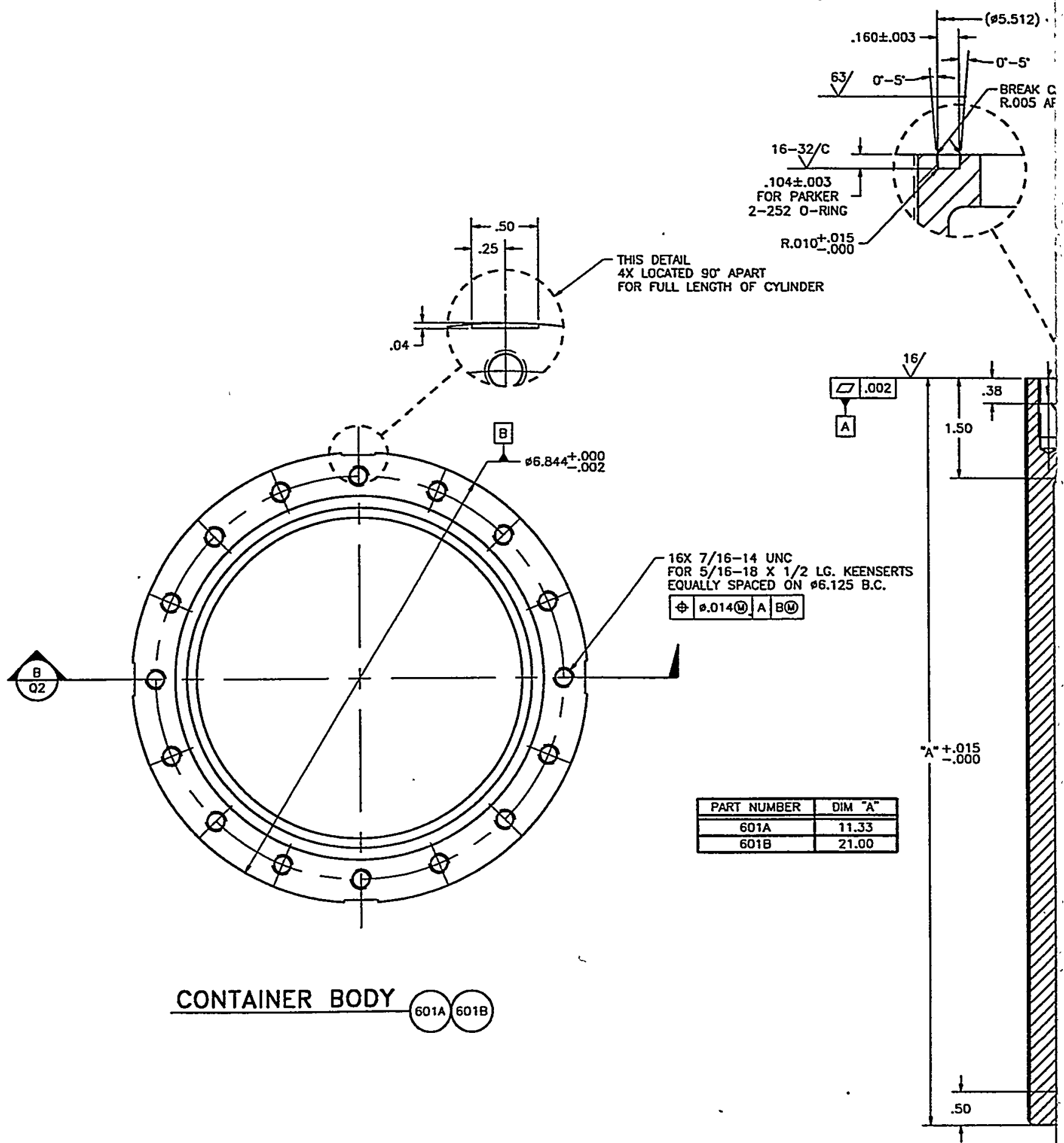




\begin{tabular}{l}
\hline \\
$\begin{array}{l}\text { NERS } \\
\text { OX. }\end{array}$
\end{tabular}
NOTES:

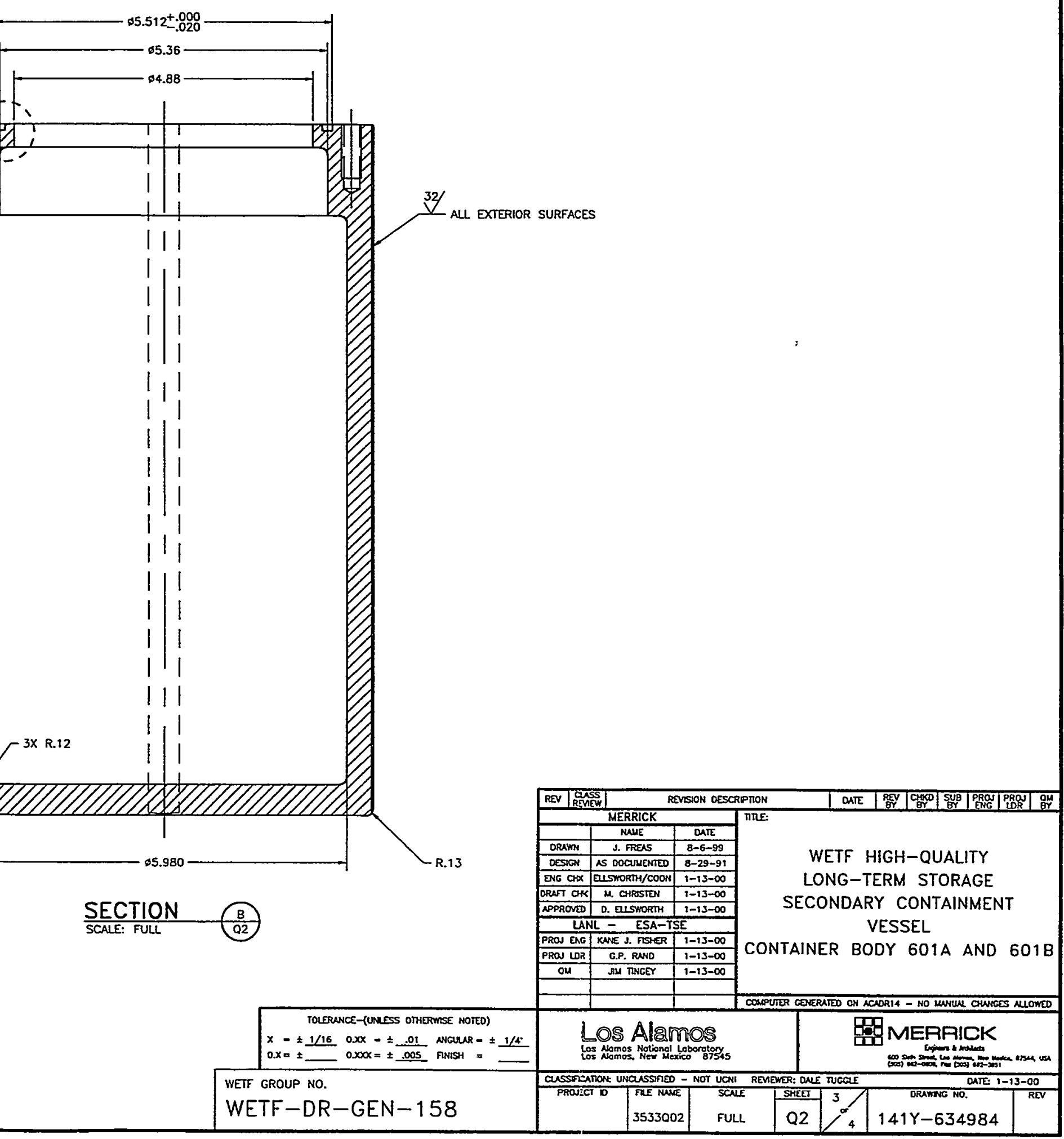

A-7 

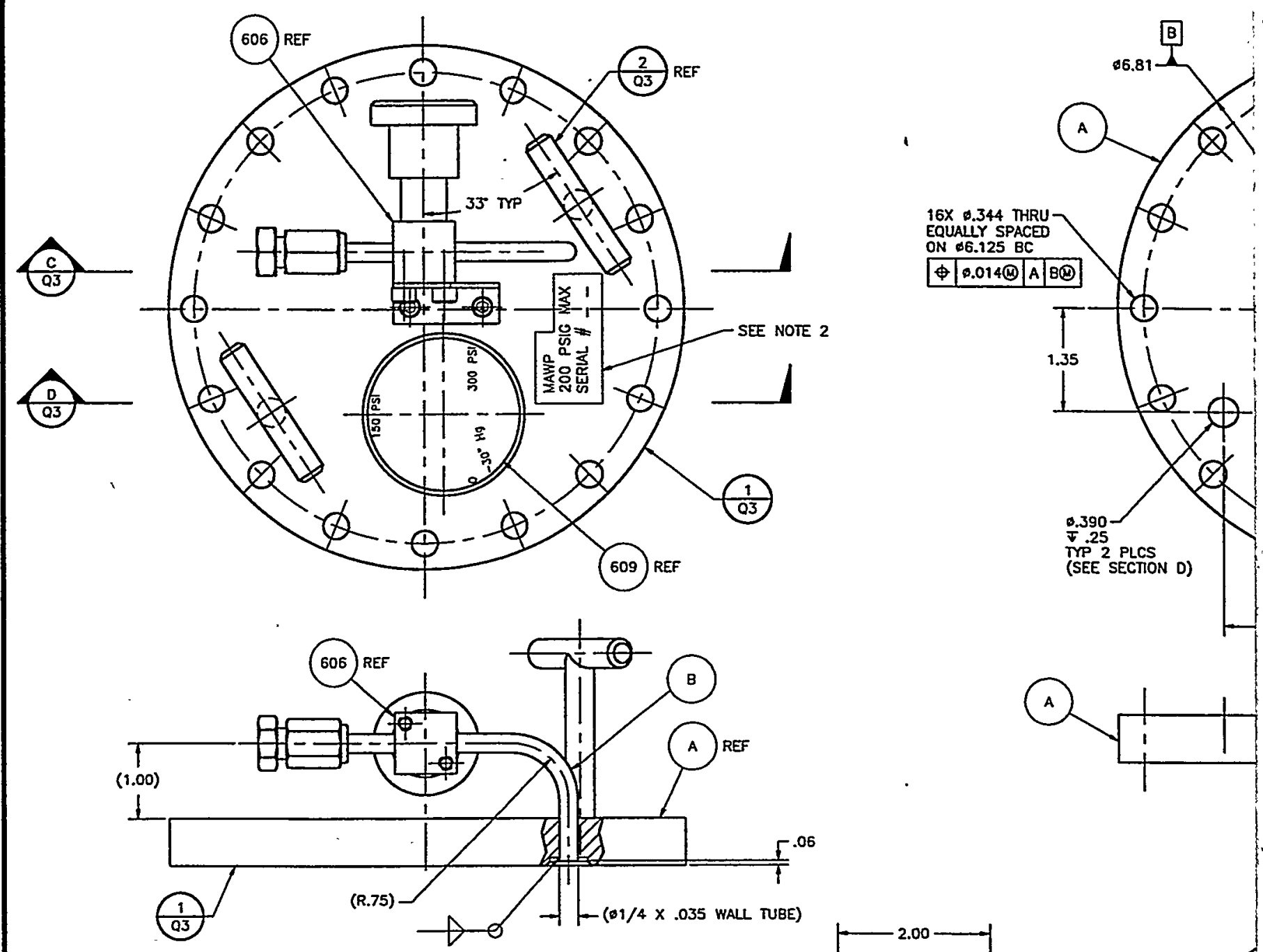

SECTION
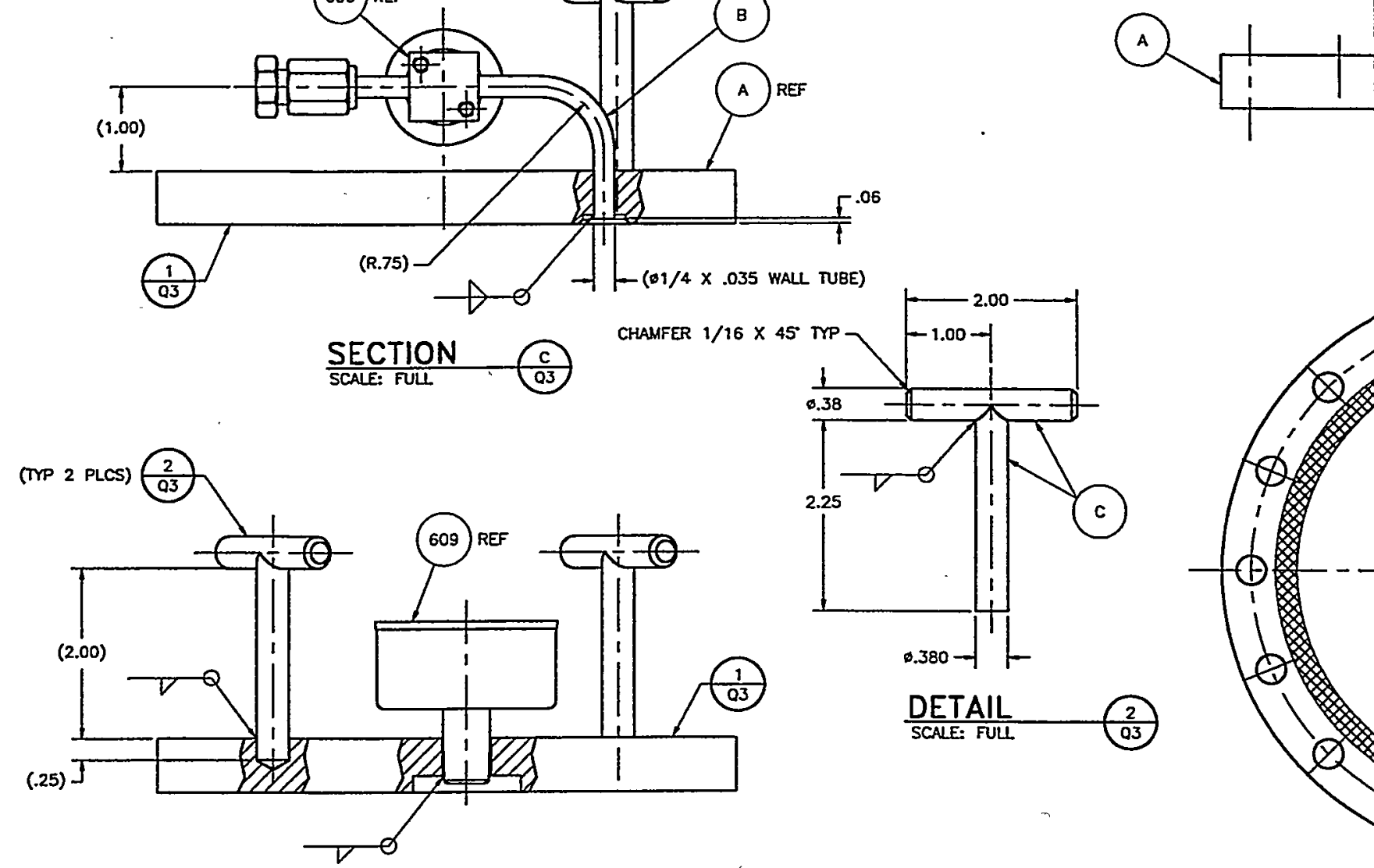

\section{SECTION}

(PART 606) REMOVEO FOR CLARIT

CONTAINER CAP WELDMENT 
ESA -MT prepared Experimental Test Instruction (ETI) 


\section{Appendix B}

Test Description: The test will consist of dropping two $31.5 \mathrm{lb}$. pressurized containers, with a dummy mass inside, onto concrete from a height of $10.0^{\prime}$. One container will be dropped at a $45^{\circ}$ angle onto the pressure gauge. The other container will be dropped at a $45^{\circ}$ angle onto the valve. The containers will be pressurized to 200 PSIG using helium. After a container has been dropped, and it has been determined that it is safe, it will be loaded into a transportation container and transported from TA-11 to TA-16, Bldg. 202. Once at Bldg. 202 a helium leak test will be performed. Once removed from $\mathrm{K}$-site, Bldg. 202 safety procedures should be followed for removal from the transportation container and testing of the dropped container.

\section{Hazards Present:}

1) The container is pressurized to 200 PSIG. Similar containers have been leak checked to at least 2,000 PSIG.

2) Lifting and rigging is required.

\section{Hazard Evaluation:}

1) The container could rupture.

2) Lifting and rigging equipment could fail.

\section{Hazard Management:}

Prior to testing the following SOP's and HCP's will be read by all personnel involved.

MT-SOP-GN01 General Procedures, MT Group

MT-SOP-ET01 General Procedures, Dynamic Testing

MT-SOP-ET06 Drop Tower Testing

MT-HCP-ET06 Drop Tower Testing

The following procedures will be adhered to:

1) The drop(s) will be done remotely from Bldg. K-3. The K-site Reduced Hazard Area defined by Gate 10 will be secured. All personnel on site will be in Bldg. K2, K3, K4 or K30 during the drop(s). After the container has been dropped, we will wait five minutes. After five minutes one person will go to the drop area and listen for leaking gas and inspect the container for visible damage. At no time shall any personnel put his/her body parts in front of the valve/gauge end of the container. The following procedures will be followed after the drop(s).

A) If there is no audible evidence of leakage. WETF personnel will approach from the back end of the unit, (the non-valve end), and use a helium leak detector to determine if there is leakage. If there is evidence of leakage, WETF personnel will use the helium leak detector every fifteen minutes until there is no evidence of leakage. When there is no evidence of leakage go to $C$. 


\section{Appendix B}

B) If there is audible evidence of leakage. Wait until the audible leakage has stopped. WETF personnel will approach from the back end of the unit (the non-valve end), use a helium leak detector to determine if there is leakage. If there is evidence of leakage, WETF personnel will use the helium leak detector every fifteen minutes until there is no evidence of leakage. When there is no evidence of leakage go to $C$.

C) One person will lift the container, with the gauge/valve end away from his/her body, and put it into the transportation container. The transportation container will be closed and transported to Bldg. 202. Knowledgeable Bldg. 202 personnel will accompany the container so as not to endanger unsuspecting 202 personnel receiving the container.

2) The crane and drop mechanism will be inspected prior to lifting the container for the drop. The container will be placed on a hydraulic lift and raised to approximately $4.0^{\prime}$. The container will be lifted approximately 1 " to allow the correct orientation to be verified and the hydraulic lift will be removed. The remainder of the lift will be done remotely from Bldg. K-3.

3) All personnel that go to the drop tower area shall wear a hard hat. After the drop(s), any personnel that go to the drop tower area shall wear eye protection until the transportation container has been removed from the area.

\begin{tabular}{|c|c|c|c|}
\hline HAZARD & SEVERTTY & LIKELIHOOD & RISK \\
\hline Violent Release of Pressure & Critical & Improbable & Low \\
\hline Slow Release of Pressure & Negligible & Probable & Minimal \\
\hline Lifting & Moderate & Remote & Minimal \\
\hline
\end{tabular}
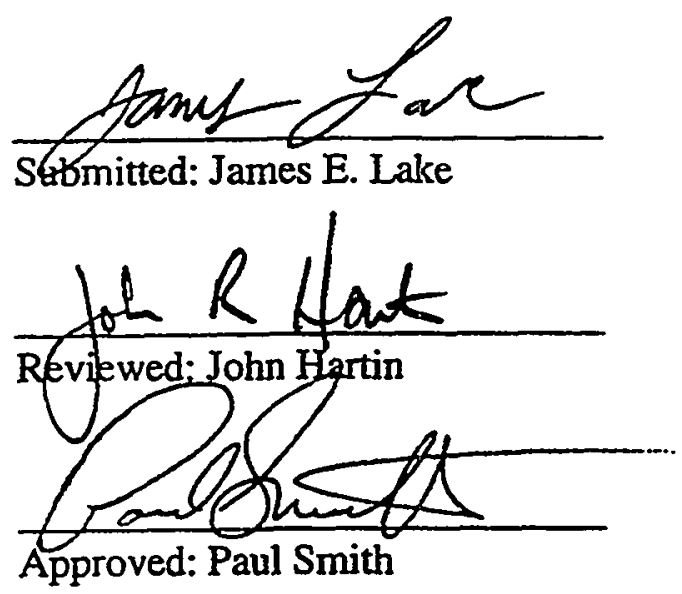

$\frac{18-\varepsilon-9 q}{\text { Date }}$

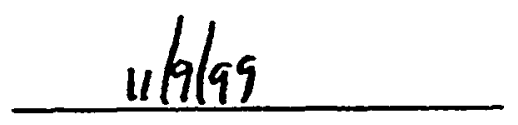

Date

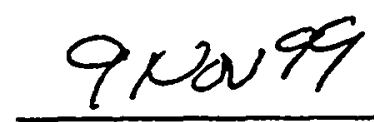

Date 


\section{Appendix C}

Photocopy of ASME calculations by James Radigan, PE 


\section{Appendix C}


James Radigan

P.O. Box 39278

Denver, CO 80239

Sept. 29, 1999

Kane J. Fisher

Los Alamos National Laboratory

P.O. Box 1663

Mail Stop C927

Los Alamos, NM 87545

Mr. Fisher,

Attached please find the transcribed calculations for the Long-Term Storage Container.

In the transcription process, I found two errors in my original hand calculations which I wish to bring to your attention. Neither error affected the final analysis, but were corrected for the sake of completeness.

The first error is in the external pressure calculations for the shell, where an exponent was mis-copied from one equation to the next. This error was corrected during transcription and resulted in a more accurate result for the stresses in the shell under vacuum conditions.

The second error is in the calculation for the stainless steel top cover. An erroneous value was used for one of the variables. This error was also corrected during transcription and resulted in a lower stress value for the top cover.

Based on this analysis, the design of the Long-Term Storage Container is adequate for the pressure conditions specified.

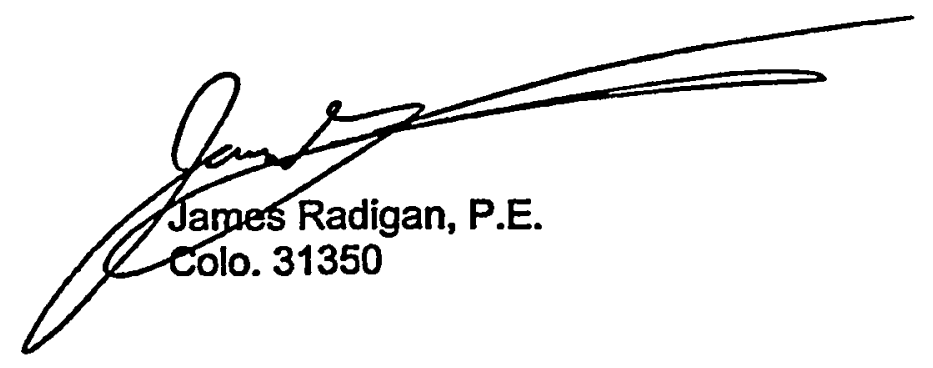




\section{Appendix C}

\section{Los Alamos National Laboratory \\ Long-Term Storage Container}

Materials: Container: 8-211 - 2024-T351 Aluminum

$v=0.334$

Lid: A-240-304 Stainless Sted

$v=0.305$

Prossuro:

200 psi (internal)

15 psi (external)

Aluminum:

$$
\begin{aligned}
S & =S u / 4 \\
& =62,000 / 4 \\
& =15,500 \mathrm{pol} \\
S_{y} & =45,000 \mathrm{poi}
\end{aligned}
$$

$\sigma_{\text {mex }}=$ Lesser Ot.

$$
\text { or }^{1.5 * 15,500}
$$

$(2 / 3) * 45,000$

$=23,250 \mathrm{pss}$

or

$=30,000 \mathrm{pol}$

Therefore, $\sigma_{\max }=23,250 \mathrm{psi}$

Stainless: $\quad \sigma_{\max }=18,800 \mathrm{psi}$ 


\section{Appendix C}

Shell:

Internal Pressure: $\quad$ (ref.: Roark's Formulas for Stress \& Strain, 6th ed., Table 28 Case 1C)

$$
\begin{aligned}
& \sigma_{1}=\text { Longitudinal Stress } \\
& \sigma_{2}=\text { Hoop Stress } \\
& \sigma_{1}=\left(q^{*} R\right) /(2 * t) \quad \text {. } \quad q=\quad 200 \text { psl } \\
& =(200 \cdot 3.209) /(2 \cdot 0.427) \quad t=0.427 \text { in } \\
& =\quad 752 \mathrm{pBi} \\
& \sigma_{2}=\left(q^{*} R\right) / t \\
& =(200 * 3.209) / 0.427 \\
& =1503 \text { psi }<23,250 \text { psi Therefore, the shell is acceptable. }
\end{aligned}
$$

External Pressure: $\quad$ (ref.: Roark, Table 29 Case 5)

$$
\begin{aligned}
& \sigma_{1}=\quad 0 \\
& \sigma 1^{\prime}=\left(-6^{*} M\right) /\left(t^{2}\right) \\
& =\left(-6^{*} 0\right) /\left(0.427^{\wedge} 2\right) \\
& M=\quad 0 \text { in-lb } \\
& t=0.427 \text { in } \\
& =0 \\
& \sigma_{2}=\left(\left(y^{*} E\right) / R\right)+\left(V^{*} \sigma 1^{\circ}\right) \quad E=10,300,000 \text { poi } \\
& y=\left(y_{A} * F_{1}\right)+\left(\left(\Psi A_{A} / 2 * \lambda\right) * F_{2}\right)+L T y \\
& R=\quad 3.209 \mathrm{ln} \\
& y A=\left(-q /\left(4^{*} D * \lambda \wedge 4\right)\right) *\left(\left(\left(2 * C_{3} * C_{23}\right)-\left(C_{4} * C_{22}\right)\right) / C_{11}\right) \\
& D=\left(E \cdot{ }^{\wedge} 3\right) /\left(12 *\left(1-V^{\wedge}\right)\right. \\
& =\left(10,300,000 * 0.427^{\wedge} 3\right) /(12 *(1-0.334 \wedge 2) \\
& =75,216 \\
& \lambda=\left(\left(3 *\left(1-v^{\wedge} 2\right)\right) /\left(R^{\wedge} 2 * \wedge^{\wedge}\right)\right)^{\wedge} 0.25 \\
& =\left(\left(3 *\left(1-0.334^{\wedge} 2\right)\right) /\left(3.209 \wedge 2 * 0.427^{\wedge} 2\right)\right)^{\wedge} 0.25 \\
& =1.092
\end{aligned}
$$




\section{Appendix C}

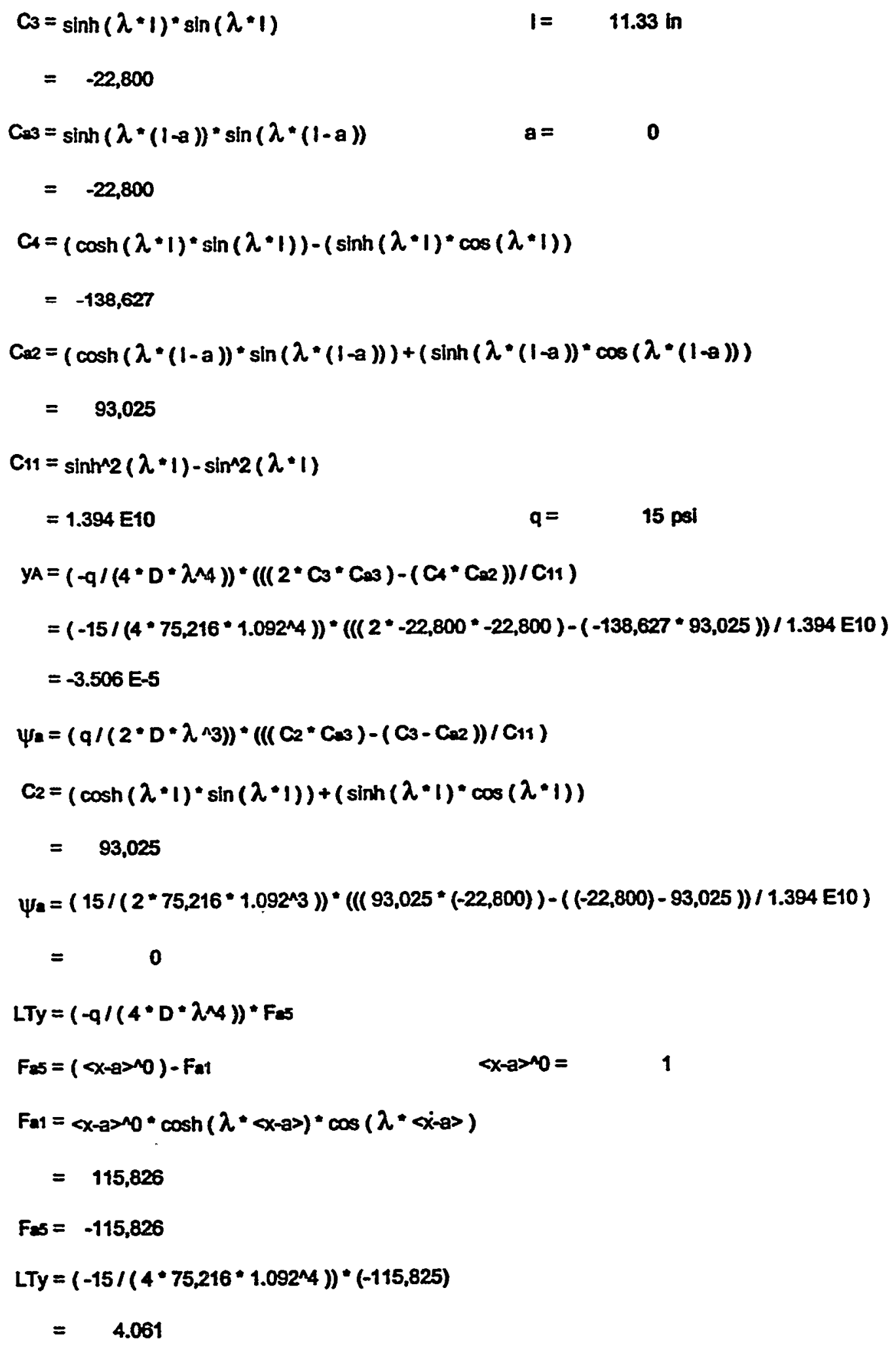




\section{Appendix C}

$$
\begin{aligned}
F_{1} & =(\cosh (\lambda \cdot 1) * \cos (\lambda \cdot 1)) \\
& =115,826 \\
y & =((-3.506 \mathrm{E}-5) * 115,826)+0+4.061 \\
& =1.404 \mathrm{E}-4 \\
\sigma_{2} & =((1.404 \mathrm{E}-4 * 10,300,000) / 3.209)+0 \\
& =\quad 450 \mathrm{psi}<23,250 \mathrm{psi} \quad \text { Therefore, the shell is acceptable. }
\end{aligned}
$$

$$
\begin{aligned}
& \text { Bottom End: (Note: Internal pressure will govern ) } \\
& \text { (ref:: Roark, Table } 24 \text { Case 10b) } \\
& \sigma=\left(6^{*} M+\left(t^{*} 2\right)\right) \\
& t=0.5 \text { in } \\
& M_{t}=\left(\theta \cdot D \cdot\left(1-V^{\wedge} 2\right) / r\right)+(V \cdot M r) \quad r=2.995 \text { in } \\
& \theta=\left(\left(M_{c} * *\right) /(D *(1+V))+L T \theta\right. \\
& M c=\left(q^{*} a^{\wedge} 2 *(1+V)\right) / 16 \\
& =(200 * 2.995 \wedge 2 *(1+0.334)) / 16 \\
& \text { ro }=0 \mathrm{ln} \\
& a=2.995 \mathrm{ln} \\
& q=200 \mathrm{pol} \\
& =149.58 \\
& D=\left(E * t^{\wedge} 3\right) /\left(12 *\left(1-V^{\wedge} 2\right)\right. \\
& E=10,300,000 \mathrm{pol} \\
& =\left(10,300,000 * 0.5^{\wedge} 3\right) /\left(12^{*}\left(1-0.334^{\wedge} 2\right)\right. \\
& =120,764 \\
& L T_{\theta}=\left(-q \cdot m 3 \cdot G_{14}\right) / D \quad G_{14}=0.0625 \\
& =(-200 \cdot 2.895 \wedge 3 * 0.0625) / 120,764 \\
& =-0.00278 \\
& \theta=((149.58 \cdot 2.995) /(120,764 *(1+0.334))-0.00278 \\
& =8.466 \mathrm{E}-7 \\
& M_{t}=M_{c}+L_{T M} \\
& L T M=-q * m_{2} * G_{17} \\
& G_{17}=(3+v) / 16 \\
& =0.2084
\end{aligned}
$$




\section{Appendix C}

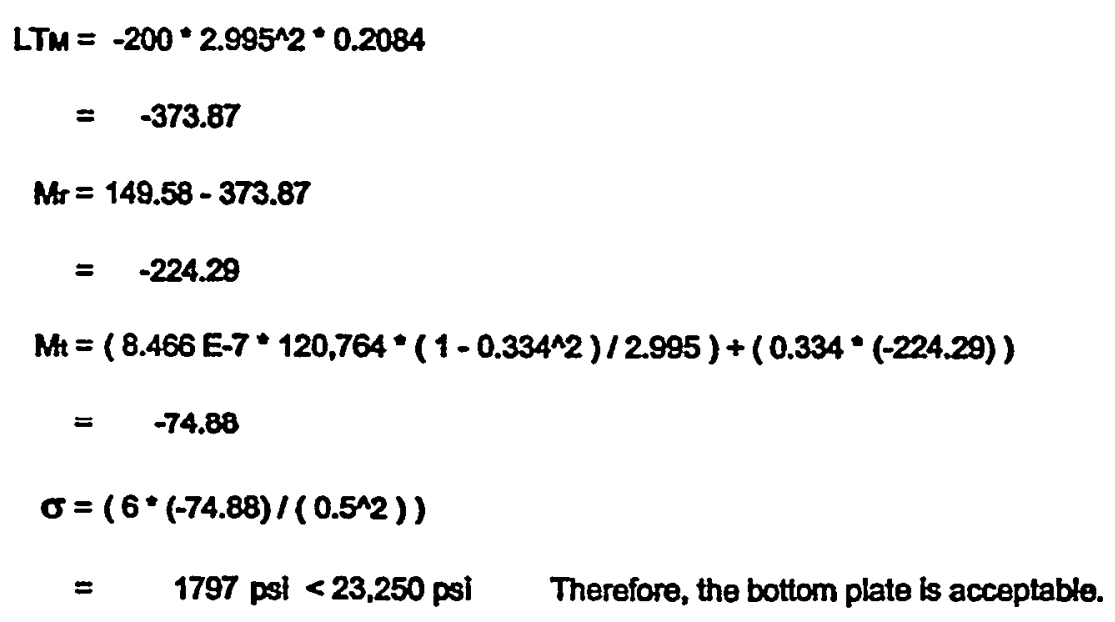

Top Cover:

$$
\begin{aligned}
& \sigma=\left(6^{*} \operatorname{Mt} /\left(t^{\wedge} 2\right)\right) \\
& M_{t}=\left(\theta \cdot D *\left(1-V^{\wedge} 2\right) / r\right)+\left(V * M_{r}\right) \\
& \theta=\left(\left(M_{c}^{*} r\right) /\left(D^{*}(1+V)\right)+L T_{\theta}\right. \\
& M_{c}=\left(q^{*} a^{\wedge} 2 *(1+v)\right) / 16 \\
& =(200 * 2.44 \wedge 2 *(1+0.305)) / 16 \\
& =97.12 \\
& D=\left(E * t^{\wedge} 3\right) /\left(12 *\left(1-v^{\wedge} 2\right)\right. \\
& =\left(27,600,000 * 0.625^{\wedge} 3\right) /\left(12 *\left(1-0.305^{\wedge} 2\right)\right. \\
& =619.117 \\
& L T_{\theta}=\left(-q * m 3 * G_{14}\right) / D \\
& G_{14}=\quad 0.0625 \\
& =\left(-200 * 2.44^{\wedge} 3^{*} 0.625\right) / 619,117 \\
& =-2.933 E-4 \\
& \theta=((97.12 \cdot 2.44) /(619,117 *(1+0.305))-2.933 E-4 \\
& =5.866 \mathrm{E}-5 \\
& M_{r}=M c+L T M \\
& L T M=-q * M_{2} * G_{17} \\
& t=0.625 \text { in } \\
& r=2.44 \text { in } \\
& v=\quad \dot{0} .305 \\
& a=\quad 2.44 \text { in } \\
& E=27,600,000 \mathrm{psi}
\end{aligned}
$$




\section{Appendix C}

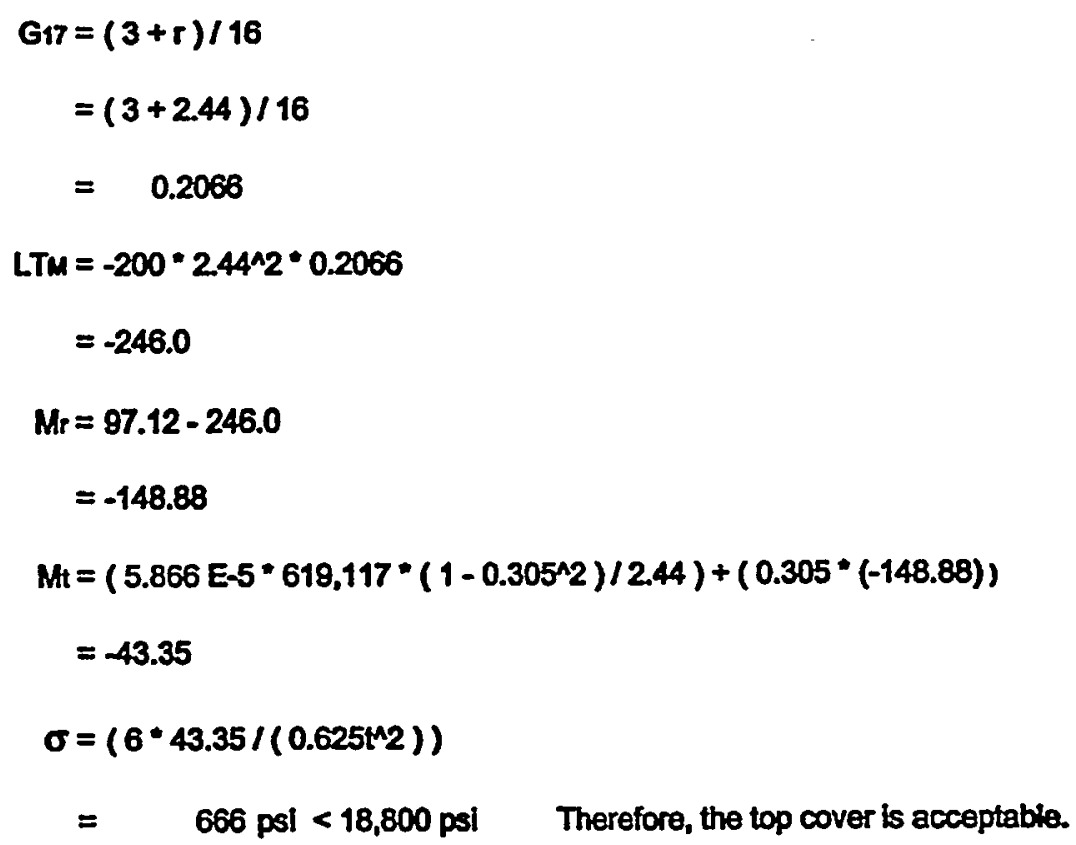

Bolting:

End Load:

$$
\begin{array}{rlrl}
F & =q * A & q= & 200 \mathrm{pol} \\
A & =\pi * d \wedge 2 / 4 & d= & \\
& =\pi * 4.88 \wedge 2 / 4 & \\
& =18.70 \mathrm{in} / 2 & \mathrm{in} \\
F & =200 * 18.70 \\
& =3740 \mathrm{lb} \\
L & =F / n \\
& =3740 / 16 \\
& =234 \mathrm{lb}
\end{array}
$$

Assume 5/15-18 UNC bolts

$$
\begin{aligned}
\sigma & =L / A_{0} \quad A D=0.0524 \text { inf2 } \\
& =234 / 0.0524 \\
& =4466 \mathrm{psi}<18,800 \mathrm{psl} \quad \text { Therefore, the bolting is acceptable. }
\end{aligned}
$$

This same $234 \mathrm{lb}$ load will also act on each insert. 


\section{Appendix C}

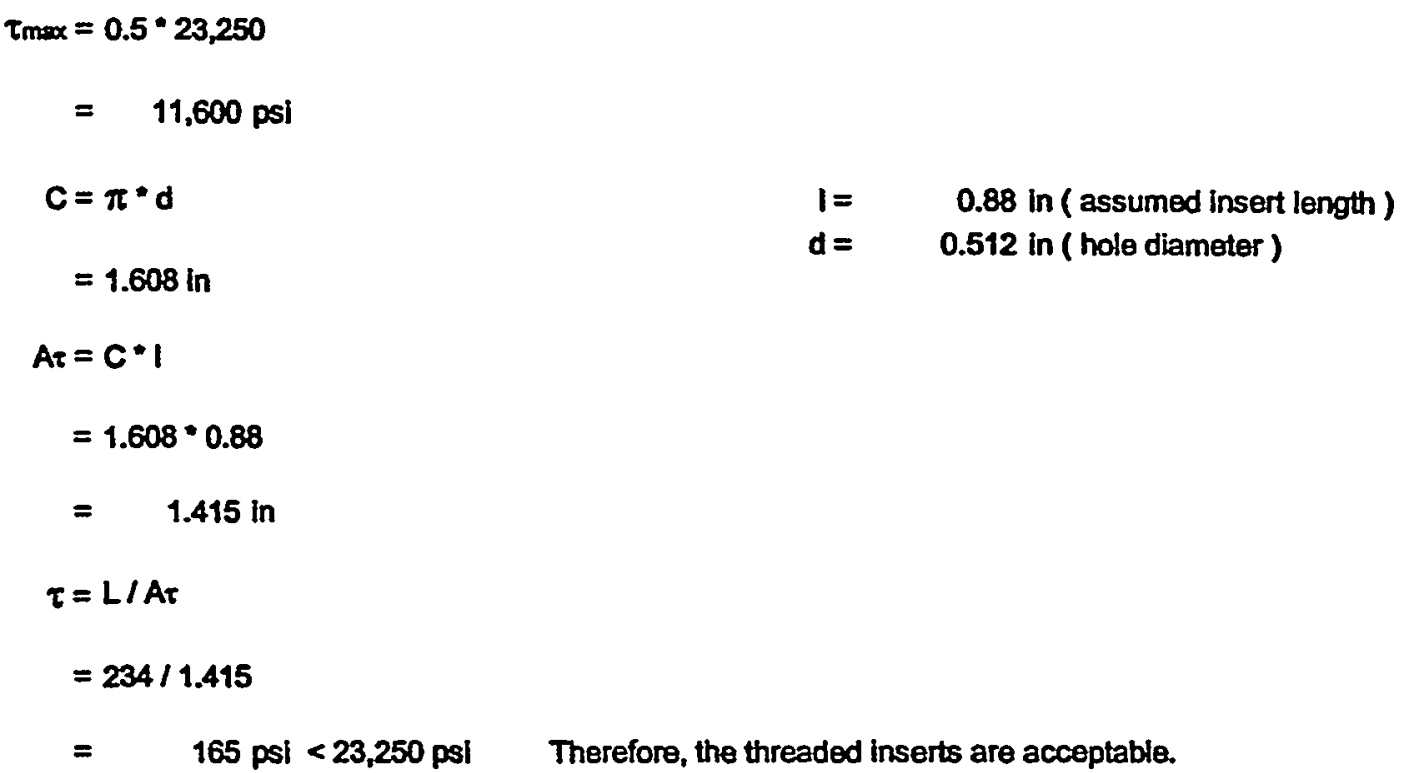




\section{Appendix D}

\section{Kaiser Aluminum \& Chemical} Corporation material certification report 
Appendix D 


\section{Appendix D}

MADE IN USA
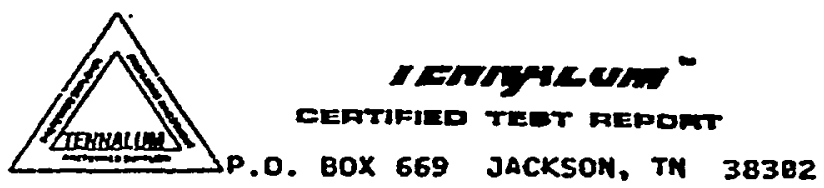

SOLD BRALCO METALS

15090 NORTHAM STREET

SHIP BRALCO METALS
FO 15090 MORTHAM STREET

LA MIRADA, CA USA 90630

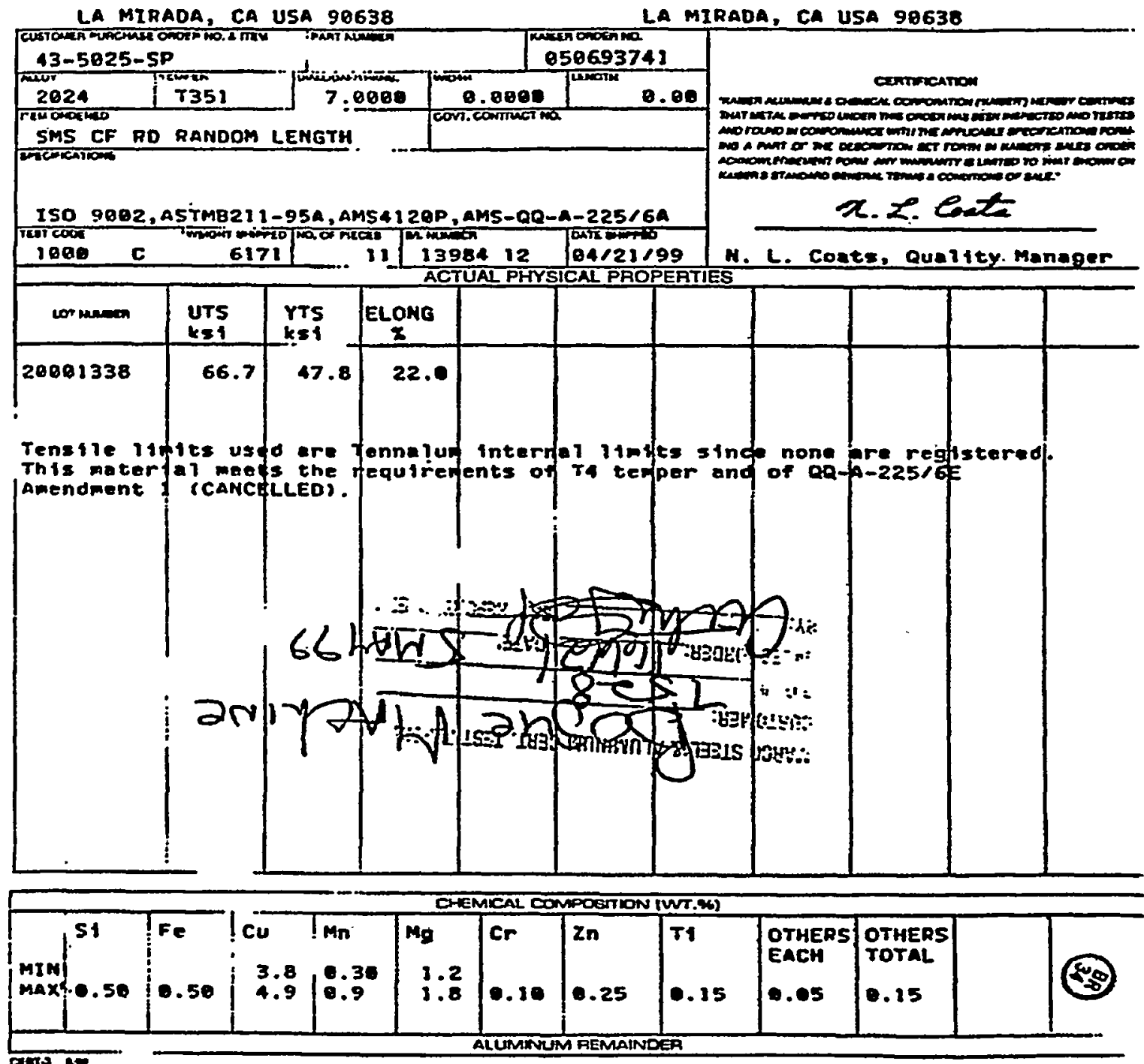

s/190

SOLD TO: MARCO STEEL PONUMBER: ABQ25489 PART NUMBER.

BRALCO ORDER NUMBER: 88451 WEGGHT (LBS):6171 PIECES:

TR CIERK SIGNATURE:

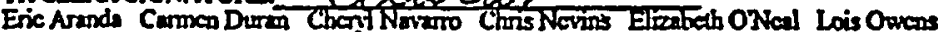
COMMENT: 


\section{Appendix D}

D-4 


\section{Ugine-Savoie, France, certificate of tests for the bar stock 304L}




\section{Appendix E}




\section{Appendix E}

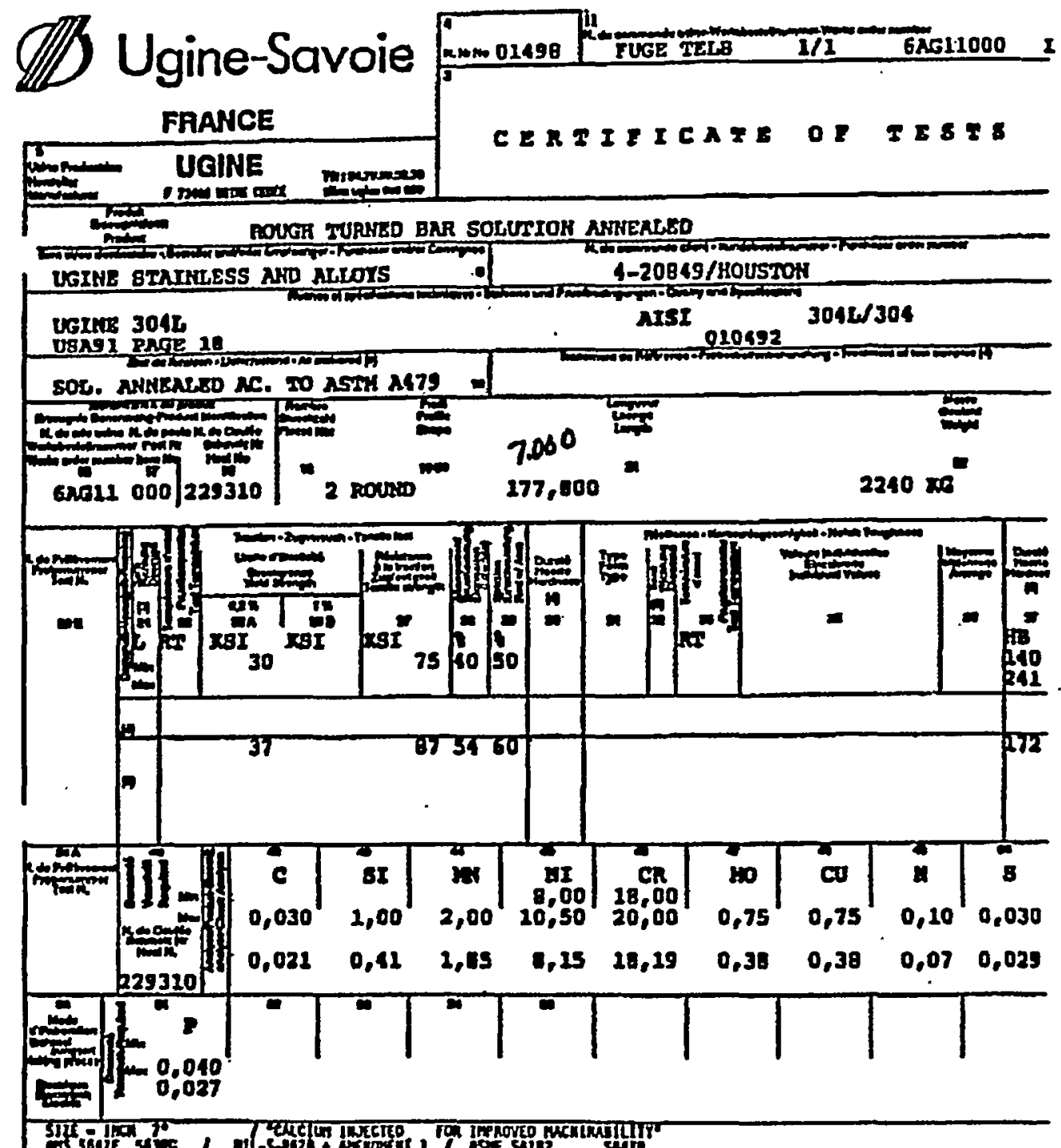

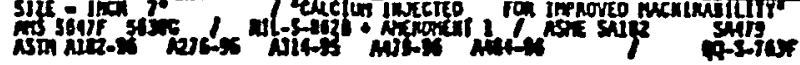

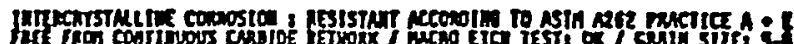

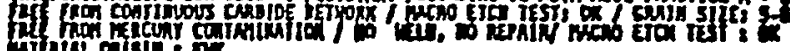
minter onitsin : and

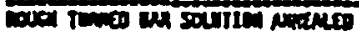
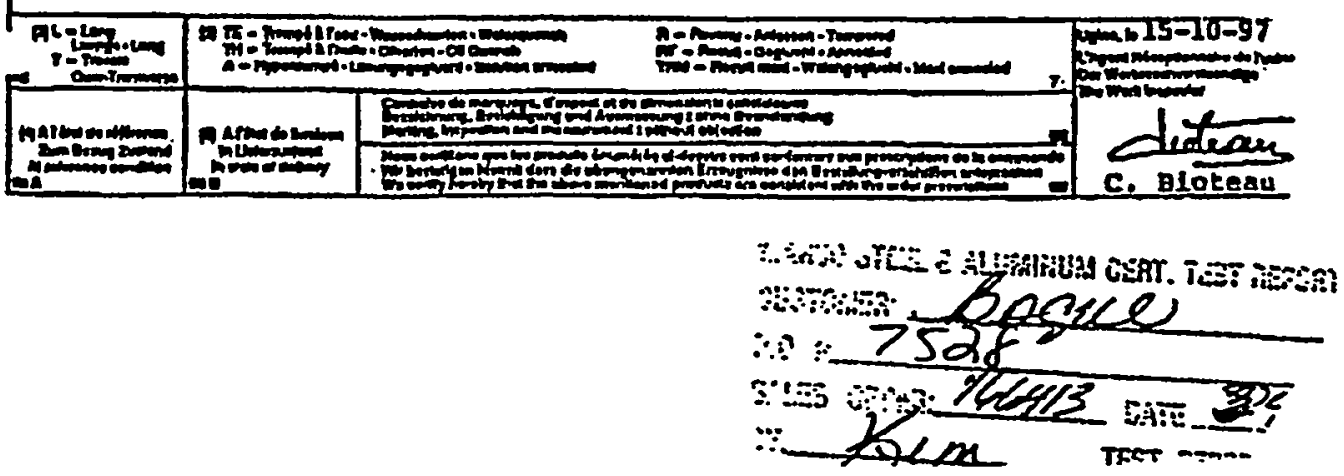
Appendix E

E-4 